\title{
The Development and Function of Regulatory T Cells
}

\author{
Creg J. Workman ${ }^{\star}$, Andrea L. Szymczak-Workman ${ }^{\star}$, Lauren W. Collison ${ }^{\star}$, Meenu R. Pillai ${ }^{\star}$, \\ and Dario A.A. Vignali ${ }^{\dagger}$ \\ Department of Immunology, St. Jude Children's Research Hospital, Memphis, TN 38105, USA.
}

\begin{abstract}
Regulatory $\mathrm{T}$ cells [Tregs] are a critical subset of $\mathrm{T}$ cells that mediate peripheral tolerance. There are two types of Tregs: natural Tregs, which develop in the thymus, and induced Tregs, which are derived from naive $\mathrm{CD} 4^{+} \mathrm{T}$ cells in the periphery. Tregs utilize a variety of mechanisms to suppress the immune response. While Tregs are critical for the peripheral maintenance of potential autoreactive $\mathrm{T}$ cells, they can also be detrimental by preventing effective anti-tumor responses and sterilizing immunity against pathogens. In this review, we will discuss the development of natural and induced Tregs as well as the role of Tregs in a variety of disease settings and the mechanisms they utilize for suppression.
\end{abstract}

\section{Keywords}

Regulatory T cells; Foxp3; peripheral tolerance; inflammatory bowel disease; allergy; type 1 diabetes; multiple sclerosis; tumors

\section{Introduction}

The immune system uses many mechanisms to maintain immunologic self-tolerance and protect the host against exacerbated responses to foreign antigens. The existence of regulatory $\mathrm{T}$ cells [Tregs] that actively suppress the function of conventional $\mathrm{T}$ cells is a key mechanism by which the immune system limits inappropriate or excessive responses. The concept of 'suppressor' T cells has been around since the early 1970's [1,2] but because of the difficulty in proving their existence, due to the absence of the molecular and cellular tools we enjoy today, this concept was largely forgotten and relegated to phenomenology. In 1995, a landmark study by Sakaguchi and colleagues described a unique $\mathrm{CD} 4{ }^{+} \mathrm{CD} 25^{+} \mathrm{T}$ population that had potent regulatory activity [3]. In order to avoid the lingering skepticism that still surrounded 'suppressor' T cells, this sub-population was referred to as regulatory T cells [Tregs]. This discovery reawakened interest in the concept that there were specific subpopulations that could inhibit and regulate the immune response. In 2003, the Treg field made another significant leap forward with the discovery of Foxp3, a forkhead family transcription factor, as a critical regulator of Treg development, function and homeostasis [4-6]. Genetic mutations in the gene encoding Foxp 3 have been identified in both mice and humans [6,7]. The importance of Tregs first became apparent in patients with mutations in Foxp 3 who develop a severe, fatal systemic autoimmune disorder called Immune dysregulation Polyendocrinopathy Enteropathy X-linked (IPEX) syndrome, [8]. IPEX patients present at an early age in males and causes severe enlargement of the secondary lymphoid organs, insulin-dependent diabetes, eczema, food allergies and concomitant infections. Currently the only cure is bone marrow transplantation.

Correspondence: Dr. Dario Vignali, Department of Immunology, St. Jude Children's Research Hospital, 262 Danny Thomas Place, Memphis, TN 38105-3678, USA. Tel: 901-595-2332. FAX: 901-595-3107. E-mail: E-mail: vignali.lab@stjude.org.

These authors contributed equally. 
A spontaneous Foxp 3 mutation in mice, known as "scurfy", results in symptoms that that are very similar to that seen in IPEX patients. It quickly became apparent that Tregs were very important regulators of peripheral tolerance and immune responses.

There are two types of CD4+ Tregs, 'natural' Tregs (nTregs) and induced Tregs (iTregs), which are primarily defined by where they develop. nTregs develop in the thymus during the course of positive and negative selection, while iTregs develop in the periphery from conventional $\mathrm{CD}^{+} \mathrm{T}$ cells following antigenic stimulation under a variety of conditions. Both nTregs and iTregs must achieve a fine balance between maintaining peripheral tolerance by suppressing potential autoimmune responses, while also controlling responses to infections. Often achieving this balance can be contradictory with Tregs overperforming or underperforming. For instance, Tregs have been shown to dampen local anti-tumor responses and prevent sterilizing immunity against certain chronic infectious agents. On the other hand, Tregs can occasionally be ineffective in mediating peripheral tolerance leading to an exacerbated inflammatory/allergic reaction or autoimmunity. Given this paradigm, therapeutic targeting of Tregs will have to be carefully controlled to ensure that cancer, for instance, is not replaced with rampant autoimmunity.

In this review, we will cover the development and function of both nTregs and iTregs, providing a brief overview of the various mechanisms used by Tregs to mediated suppression. We will illustrate the role of both Treg populations, as well as the mechanisms they utilize, in several contrasting disease settings. While most of the focus of this review is on murine Tregs, studies with human Tregs have been highlighted throughout.

\section{Development of nTregs}

nTregs, like all $\mathrm{T}$ cells, arise from progenitor cells in the bone marrow and undergo their lineage commitment and maturation in the thymus (Figure 1). nTregs comprise a small population, only $\sim 5-10 \%$ of peripheral $C D 4^{+} \mathrm{T}$ cells [9], however their existence is vital. nTregs migrate from the thymus into the periphery after day 3 of life, and thymectomy of mice at day 3 results in lethal autoimmunity due to the lack of peripheral Tregs [10].

While there is no cell surface marker that uniquely identifies nTregs, there are a number cell surface proteins that are preferentially expressed on nTregs (Figure 1). The first identified was the high affinity IL-2 receptor $\alpha$ chain, CD25 [3]. This seminal discovery suggested that CD25 could be used as a marker for Tregs. However, CD25 is not unique to nTregs, as conventional T cells express CD25 when activated by T cell receptor (TCR) ligation. Since this original publication, numerous studies have been dedicated to the identification of specific cell surface markers expressed by nTregs. Purification of human nTregs, but not murine nTregs, can be enhanced by excluding $\mathrm{T}$ cells that express CD127. It has recently been shown that CD127 expression is inversely correlated with Foxp3 expression and suppressive capacity of nTregs [11]. It is well known that activation of a conventional T cell requires both TCR ligation as well as signaling through co-stimulatory molecules. Therefore, it is not surprising that nTregs express both effector molecules, such as CTLA-4, LAG-3, CD39 and CD73, and costimulatory molecules, such as CD28, CD80/86 (B7), CD40, OX40 and 4-1BB [12-14]. However, none described to date are restricted to Tregs [14]. Other molecules that may be useful surface markers of nTregs, but whose functions are not clearly elucidated yet, include neuropilin-1 and folate-receptor 4 (FR4). The most specific marker of Tregs is Foxp3, which is expressed exclusively in thymus-derived nTregs and certain peripheral iTreg populations that have suppressive capabilities. However due to its nuclear expression, Foxp3 cannot be used to purify or mark nTregs [5,6]. In contrast to murine $\mathrm{T}$ cells, human $\mathrm{CD} 4^{+} \mathrm{CD} 25^{-} \mathrm{T}$ cells that are activated can upregulate expression of Foxp3 without acquiring suppressive capacity [15]. However, genetic mutations in the gene encoding Foxp3 are fatal for both mice and 
humans [6,7]. These findings suggest that although not all Foxp3 $3^{+}$human $\mathrm{T}$ cells are suppressive, Foxp3 still appears to be the "master regulator" of nTreg development and function. In accordance with its important role in nTreg function, it was also demonstrated that conventional T cells forced to express Foxp 3 via retroviral transduction acquired regulatory capacity both in vitro and in vivo [4,5].

Signals that influence the development of nTregs in vivo are not entirely clear. However, it is known that nTreg development is influenced by co-stimulatory molecules and cytokines, TCR and antigen affinity, and the location and context within the thymus where antigen is encountered.

\section{Co-stimulatory Molecules and Cytokines}

Like conventional $\mathrm{T}$ cells, Tregs are selected by peptides presented by antigen presenting cells (APCs) in the thymus. However, co-stimulatory molecules such as CD28 [16], CD80/86 (B7), CD40 [12] and IL2r $\beta$ [17] appear to be especially critical for the development of nTregs. Mice deficient in these molecules have reduced numbers of nTregs with impaired suppressive capacity. Also critical to the development of nTregs are IL-2 and, to a lesser degree, TGF $\beta$. Although nTregs express the high-affinity IL-2 receptor CD25, they do not make IL-2 themselves due to chromatin inaccessibility of the IL-2 locus [18]. Consequently, nTregs are absolutely dependent upon paracrine IL-2 for survival and growth. In addition to IL-2, TGF $\beta$ also appears to play a role in the development of nTregs. It was originally thought that nTreg development was independent of TGF $\beta$ since Treg development is unaltered in TGF $\beta$ receptor dominant negative mice [19]. However, it was recently shown that sustained TGF $\beta$ is required to maintain Foxp3 expression and suppressor function of peripheral nTregs both in vitro and in vivo [20]. Clearly, further studies will need to be performed to determine whether TGF $\beta$ has an analogous role in the thymus.

\section{TCR Ligation, Strength of Signal and Self-Peptides}

Conventional $\mathrm{T}$ cells undergo selection in the thymus based on the strength of signal they receive from thymic APCs [DCs, medullary (mTEC) or cortical epithelial cells (cTEC)] presenting self peptides. Strong signals due to high affinity or avidity interactions between the TCR and MHC:peptide complexes results in negative selection. No or very low signal leads to thymocyte death by neglect. Positive selection of thymocytes that will survive and populate the periphery occurs when intermediate to weak signals are delivered via engaged TCR (reviewed in [21]). However, it has been suggested that nTregs differ in the selection process in that they are positively selected on a TCR affinity/signal strength that is between that required for the positive and negative selection for conventional T cells [22]. Like conventional T cells, nTregs have a polyclonal TCR repertoire and are selected on self-peptides. However, unlike conventional $\mathrm{T}$ cells, Tregs appear to have more exacting requirements regarding the composition of self and the amount of signal required for their development as they usually do not develop in mice that express a single TCR [23]. However, Treg development is restored if a significant amount of the cognate antigen for which the TCR is specific is expressed in the thymus. To further study the affinity of nTregs for self-peptides, TCR genes from a large cohort of conventional $\mathrm{T}$ cells and nTregs were cloned and sequenced [24]. Like TCRs from conventional T cells, nTreg TCRs were extremely diverse, but the overlap between TCR sequences of conventional T cells and nTregs was minimal, approximately 15-20\%. However, unlike conventional $\mathrm{T}$ cells, nTregs were capable of recognizing and signaling in response to self-peptides. More recently, hundreds of conventional T cell and nTreg TCRs were sequenced and quite different conclusions drawn [24,25]. In these studies, the data suggest that nTregs do not preferably recognize self-antigens, but instead express a polyclonal TCR repertoire that is comparable to conventional $\mathrm{T}$ cells. Collectively, these contrasting conclusions suggest that significantly more analysis will be required before firm conclusions can be made. 
While some of these data suggest that nTregs have "self-reactive" TCRs, an alternative theory is that nTregs simply have a lower activation threshold than that of conventional $\mathrm{T}$ cells. It is important to note that in essence all selected TCRs are self reactive. If they were not, they would not have driven positive selection. So the more important criterion might be the combination of TCR affinity for self, coupled with the differential ability of conventional versus regulatory $\mathrm{T}$ cells to propagate a signal that mediates a functional outcome. Indeed, it has been shown that human Tregs are responsive to TCR stimulation at 10- to 100-fold lower antigen concentrations than that required to activate a human conventional $\mathrm{T}$ cell [26]. This sensitivity may, in part, be the result of their expression of additional or enhanced levels of certain co-stimulatory and/or accessory molecules. Alternatively, there may be differences in the strength or efficiency of the TCR:CD3 signaling cascade. While it has been previously demonstrated that nTregs require activation to achieve optimal suppression regardless of the antigen specificity of the target cell $[27,28]$, recent evidence suggests that nTreg activation may not be required to achieve some level of suppression [29]. This suggests that the requirements needed to initiate trademark responses, proliferation or suppression, are different between conventional $\mathrm{T}$ cells and nTregs, respectively. Moreover, when bone marrow cells were transduced to express a nTreg-derived TCR and adoptively transferred into irradiated mice, the ratio of nTreg:conventional $\mathrm{T}$ cell was dramatically increased [30]. However, such analysis has so far only been conducted on a very limited number of Treg-derived TCRs and thus additional studies are required before a definitive conclusion can be drawn.

It has also been suggested that the self-peptides that mediate selection of nTregs in the thymus may also promote their expansion and the conversion of conventional Tregs into "induced" Tregs (iTreg) in the periphery [31]. However, as highlighted above more recent studies have suggested that there is nothing 'unique' about the TCR repertoire expressed by nTreg and that they do not preferentially have a higher affinity for self-antigens [24,25]. Moreover, nTregs recognize foreign antigens with the same frequency as conventional $\mathrm{T}$ cells, leading some to suggest that thymic peptides that participate in selection may be different to peptides that drive proliferation and function of peripheral nTregs [25]. Therefore, it has recently been proposed that the stage at which $\mathrm{T}$ cells are committed to the Treg lineage occurs prior to TCR-mediated selection and that even weak TCR:self peptide-MHC interactions are sufficient to allow survival in the thymus [32-34].

\section{Site of $\mathbf{n T r e g}$ Development}

In addition to TCR signal strength and affinity for peptide, the context within the thymus where antigen is encountered may have an impact on whether a thymocyte is selected, deleted or becomes a Treg. Using an inducible promoter system to quantitatively alter the degree of thymic expression of an MCC-derived T cell epitope, it was shown that the absolute number of nTregs remained constant despite different degrees of expression [34]. The authors found that the number of conventional $\mathrm{T}$ cells that were deleted increased with increasing thymic antigen, however the number of nTregs was unchanged, owing to resistance to deletion. This suggests that it is not the affinity for self-peptide, but rather, the context or niche in which the $\mathrm{T}$ cells encounter antigen that is most important in determining whether the cell is selected or deleted [34].

Control of the peptide repertoire that is expressed in the thymus undoubtedly affects the $T$ cells that develop. The autoimmune regulator gene (Aire) promotes the expression of tissue-specific self-antigens by thymic medullary epithelial cells [35]. Aire expression is critical for the establishment of central tolerance toward certain self-peptides, allowing thymocytes that are strongly self-reactive to be deleted [21,36]. Aire-deficient mice develop multi-organ autoimmunity due to compromised negative selection. However, it has also been suggested that other forms of tolerance, such as impaired development of nTregs, may play a role in this 
autoimmunity. A number of reports suggest that in addition to promoting deletion of selfreactive conventional T cells, Aire-expressing stromal cells may also enhance Foxp 3 upregulation in $\mathrm{CD} 4^{+}$thymocytes and nTreg development in response to self-peptides [3739]. However, other studies have shown that in the absence of Aire, antigen specificity of the nTregs is modestly altered, but the number, frequency and function of nTregs remain intact $[21,35,40,41]$. Therefore, while it seems possible that Aire-dependent antigens may play a role in the thymic development of nTregs, this issue is controversial and still remains to be resolved.

Another currently debated issue is that of the timing and location of nTreg development. Using Foxp $3^{\text {gfp }}$ reporter mice it was shown that Foxp $3^{+}$cells are found only in the thymic medulla suggesting that nTreg development occurred relatively late in thymic development [42]. In addition, a group of epithelial cells expressed in the thymic medulla called the Hassall's corpuscles were suggested to play a role in the differentiation and development of human nTregs. Human Hassall's corpuscles express thymic stromal lymphopoietin (TSLP) which conditions thymic DCs to express CD80 and CD86. Ligation of MHC and CD80/86 by $\mathrm{CD}^{+}$thymocytes induced differentiation $\mathrm{CD} 4^{+}$thymocytes into Foxp3 ${ }^{+}$nTregs [43].

However, recent studies have challenged the idea that nTreg differentiation occurs this late in thymic development. Although Foxp 3 is not detected in the thymic cortex, some studies suggest that commitment to the nTreg lineage might occur in the cortex, at an earlier point in thymic development $[25,40,44,45]$. Indeed, by limiting the expression of MHC to mTEC, cTEC and/ or DCs it has been shown that multiple accessory cell types in both the thymic cortex and medulla are capable of mediating Treg development [45]. In further support of this hypothesis, researchers have shown that limiting the capacity of $\mathrm{CD} 4^{+} \mathrm{CD} 8^{+}(\mathrm{DP})$ thymocytes to influence early $\gamma \delta \mathrm{T}$ cell or $\alpha \beta \mathrm{T}$ cell progenitors leads to preferential differentiation of $\mathrm{T}$ cells into Foxp $3^{+}$nTregs [33]. Moreover, this appears to occur prior to, and independent of, agonist selection. Another study elegantly showed that within the thymic $\mathrm{CD} 4^{+}$population, there exists a CD25 $5^{\text {high }}$ population that represents the immediate precursors to nTregs which are primed and ready to express Foxp3 following stimulation with IL-2 or IL-15 [46]. Not only does this suggest that a precursor population exists that are poised to become nTregs, but it also suggests that in addition to TCR engagement, IL-2 and the IL-2R play a pivotal role in the development of nTregs.

\section{Maintenance of $\mathbf{n T r e g}$ Homeostasis}

Signals that are important for nTreg development also appear to be important for their maintenance in the periphery (Figure 1). By generating mice with a stop codon in the Foxp3 gene, investigators were able to monitor the transcription of the Foxp3 allele in the absence of Foxp3 protein synthesis [38]. In comparing these Tregs to nTregs, which transcribe and translate Foxp3 protein, and to conventional T cells, the authors could decipher Foxp3 proteindependent features from those associated with Foxp3 expression. Their results indicated that Foxp3 plays a critical role in the peripheral maintenance of nTreg phenotype stability, including anergy and dependence on IL-2. Therefore, it appears that in addition to its role in nTregs development, Foxp3 helps to maintain the stability nTreg features in order to preserve the nTreg lineage. TGF $\beta$ signaling in peripheral nTregs is critical to their ability to suppress a variety of cell types including Th1 cells, CD8 ${ }^{+}$cytotoxic $\mathrm{T}$ cells and NK cells [47]. In addition to this role in the function of nTregs, TGF $\beta$ is also important in maintaining Foxp3 expression, nTreg homeostasis and maintenance in the periphery [20].

Perhaps most critical to the maintenance of nTregs are CD28 and IL-2. Owing to their dependence on paracrine IL-2 for survival [18], nTregs are beholden to conventional T cells for peripheral maintenance. $C d 28$-deficient mice have reduced numbers of nTregs in the spleen and lymph nodes and the resulting nTregs have reduced suppressive capacity when compared to wild-type nTregs [48]. CD28 appears to support the survival of nTregs by enhancing IL-2 
production by conventional $\mathrm{T}$ cells in addition to maintaining CD25 expression on $\mathrm{nTregs}$ $[42,49]$. IL-2 signaling seems to be critical, not just for survival of nTregs, but also for their generation and function in the thymus and the periphery. Utilizing mice that were deficient in IL-2, IL-2R $\alpha$ and IL-2R $\beta$, studies show that while IL-2 and IL-2R $\alpha$ were dispensable for $n$ Treg thymic development, IL-2R $\beta$ was absolutely required [42]. Genetic deficiency of CD25 in humans results in similar clinical manifestations as IPEX, underscoring the importance of IL-2 in nTreg function and maintenance [50]. In addition, in both murine and human studies, neutralizing anti-IL-2 induces multi-organ autoimmunity and significantly reduces the number of nTregs in the thymus and periphery [51,52]. This suggests that both thymic development and peripheral expansion of nTregs absolutely require IL-2.

\section{Development of iTregs}

While thymically-derived nTregs play a critical role in immune homeostasis, it is clear that regulatory $\mathrm{T}$ cells can be induced from conventional, naïve $\mathrm{CD} 4^{+} \mathrm{T}$ cells both in vitro and in vivo. One of the challenges in the field of regulatory $\mathrm{T}$ cells is determining the relative contributions of nTregs versus iTregs in vivo. Indeed, it appears that the main difference between the two subsets is their origin of development (thymus versus periphery) (Figure 1). However, it has been proposed that nTregs and iTregs differ not primarily in their origin, but rather as a consequence of differentiation through antigen exposure and specific factors that are highly expressed in distinct settings [53]. The importance and contribution of each particular iTreg subset is most likely dictated by the context of the antigen and environment. Two main subsets of iTregs that are generated in the periphery have been described, based upon the cytokines that cause their induction: type 1 regulatory T cells $(\operatorname{Tr} 1)$, which are induced by IL-10 [54,55], and T helper 3 (Th3), which are induced by TGF $\beta$ [56]. While both subsets are generated in the presence of different cytokines, they exert their suppressive activity through secretion of the same cytokines that are responsible for their induction, IL-10 and/or TGF $\beta$, respectively. While TGF $\beta$ and IL-10 are the primary cytokines involved in iTreg formation, it has also been demonstrated that IL-4 and IL-13 can induce the development of Foxp $3^{+}$Tregs from Foxp $3^{-}$naïve T cells independently of TGF $\beta$ and IL-10 [57]. Both IL-4 and Il-13 signal through the IL-4R $\alpha$ chain, suggesting an essential role for this receptor in the generation of Tregs in the periphery.

There has been considerable interest in determining the role of each Tregs subset in immune function, primarily because iTregs represent a powerful therapeutic tool for autoimmune disease, inflammation and anti-tumor treatment. While they are distinct, both subsets have similar phenotypes and utilize overlapping mechanisms of suppression. Both nTregs and iTregs share cell surface markers characteristic of an activated T cell, such as CD25, CTLA-4, GITR, CD62L, CD45RB ${ }^{\text {lo }}$ (reviewed in [58]). The transcription factor Foxp3 is expressed by Th3 cells following induction. However, $\operatorname{Tr} 1$ cells do not express Foxp3, either constitutively or following activation either in vitro and in vivo [55]. Transfer of either iTregs or nTregs has been shown to prevent the development of autoimmune disease in several models as well as help promote transplantation tolerance [3,59-62]. While their phenotype and modes of suppression may be similar, nTregs and iTregs in mice appear to have different requirements for their development. While nTregs may develop in response to self antigen, or at least strongly ligating peptides in the thymus, iTregs develop in response to weaker, sub-optimal TCR stimulation and exogenous antigens in the periphery $[63,64]$. Although it remains possible that the TCR repertoire of iTregs includes high affinity for self antigens, these cells are primarily generated in inflammatory settings in the presence of anti-inflammatory cytokines. Costimulation through CD28 is also required for the generation of nTregs while iTregs are able to develop in the periphery in its absence [64,65]. Furthermore, in vitro conversion of iTregs can occur in the absence of CD28 stimulation and result in cells that remain functional following in vivo transfer [66]. In fact, recent studies have indicated that co-stimulation can 
actually hinder iTreg development in vitro, which may explain the reduced stability of Foxp3 expression and limited lifespan of iTregs stimulated in the presence of anti-CD28 antibodies $[67,68]$. Because of the potential for therapy, there has been a great deal of interest in generating and expanding human iTregs in vitro. Human iTregs have been generated in vitro using in a variety of conditions, including allogeneic DCs [69,70], anti-CD3 and 4C8 administration [71] and SEB exposure [72]. Furthermore, human iTregs could be generated in vitro in the absence of TGF $[73,74]$. Finally, one study has shown that human Tr1 cells can be generated from $\mathrm{CD}^{+} \mathrm{T}$ cells in the presence of IL-2 through the engagement of CD3 and the complement regulator CD46 [75].

In addition to strength of signal, many other factors can contribute to the generation of iTregs, including antigen and route of exposure, cytokines, tissue specific factors and APCs. Intranasal or oral exposure to antigen tends to selectively induce the generation of iTregs [76,77]. APCs play an important role in iTreg generation. Monocyte-derived DCs, including plasmacytoid dendritic cells (pDCs) can induce Treg formation [70,78,79]. DCs in the gut associated lymphoid tissue (GALT) are particularly efficient at inducing Treg formation $[76,77,80]$ as well as DCs present in tumor microenvironments [81]. It has been shown that Tregs can induce DCs to become tolerogenic [82], which in the GALT provides a positive feedback loop, in the presence of TGF $\beta$, that leads to further induction of iTreg formation [80]. In addition, it has been shown that a population of macrophages $\left(\mathrm{CD} 11 \mathrm{~b}^{+} \mathrm{F} 4 / 80^{+} \mathrm{CD} 11 \mathrm{c}^{-}\right)$in the lamina propria (LP) could induce Foxp $3^{+}$Tregs in a retinoic acid (RA)-, TGF 3 - and IL-10-dependent manner [83]. Finally, studies have shown that NKT cells can play a role in iTreg generation by induction of tolerogenic APCs in response to oral antigen [84] as well as in EAE [85]. Tregs have been shown to induce suppressive properties in other $\mathrm{T}$ cell populations, a process often referred to as 'infectious tolerance'. Early studies showed that $\mathrm{T}$ cells from tolerized animals could be transferred and retain their tolerant state [86]. It was later shown that the maintenance of this transplantation tolerance was due to Tregs inducing the conversion of the suppressed $\mathrm{T}$ cells into iTregs [87]. Others have shown that co-culture of nTregs with naïve $\mathrm{CD} 4^{+} \mathrm{T}$ cells leads to iTreg formation whose suppressive ability was dependent on the cytokines IL-10 or TGF $\beta$ $[88,89]$.

Tregs also exhibit considerable plasticity in the periphery. There have been a number of studies that have demonstrated a reciprocal relationship between Th17 cells and Tregs (reviewed in [90]). While TGF $\beta$ induces the conversion of naïve $\mathrm{CD} 4^{+} \mathrm{T}$ cells into iTregs, the addition of IL-6 and IL-21 inhibits this process and promotes Th17 conversion [91]. Furthermore, activated Tregs, which produce high levels of TGF $\beta$ differentiate into Th17 cells in the presence of IL-6 [92]. In contrast, RA drives the induction of Tregs and inhibits Th17 differentiation, presumably by enhancing TGF $\beta$ signaling and inhibiting IL-6 signaling [76].

\section{Type 1 Regulatory T Cells}

$\operatorname{Tr} 1$ cells are defined by their requirement for IL-10 for their induction and their ability to produce high levels IL-10 and TGF $\beta$ to mediate suppression (Figure 1) [54,93]. Co-culture of both mouse and human $\mathrm{CD} 4^{+} \mathrm{T}$ cells with $\mathrm{Tr} 1$ cells in transwell assays reduced the proliferative response of the $\mathrm{CD}^{+} \mathrm{T}$ cells. The addition of neutralizing antibodies to IL-10 and TGF $\beta$ reversed the action of $\operatorname{Tr} 1$ suppression, indicating an essential role for these cytokines in $\operatorname{Tr} 1$ mediated suppression [54]. While the true hallmark of Tr1 cells is high level IL-10 production, additional cytokines such as IL-5 and IFN $\gamma$ are also secreted by Tr1 cells depending upon the experimental conditions [93]. Thus far, no specific markers have been identified for $\operatorname{Tr} 1$ cells. While their proliferative capacity is low, they can expand in the presence of IL-2 and IL-15, due to the high levels of receptors for these cytokines expressed following activation [94].

However, Foxp 3 is not expressed by Tr1 cells [55] and, like TGF $\beta$-dependent converted Tregs, 
$\operatorname{Tr} 1$ cells can be generated in the absence of nTregs [95], suggesting Tr1 cells may also be developmentally distinct [55].

The induction of $\operatorname{Tr} 1$ cells is primarily mediated by IL-10 producing APCs which occur in a variety of immunological settings. Studies have shown that production of IL-10 by immature DCs (iDC), tolergenic myeloid DCs and pDCs induces the generation of Tr1 cells in transplant settings and in response to allergens, pathogens and tumor antigens in mice and humans [93] [89]. The secretion of IL-10 has been shown to be important in mediating suppression of murine and human T cells in vivo, such as those responsible for the development of inflammation in the gut $[54,96]$. Mice deficient in $I l 10$ succumb to inflammatory bowel disease (IBD), which can be prevented in young mice by the addition of exogenous IL-10. As Tr1 cells produce high levels of IL-10, transfer of these cells can prevent induction of IBD by CD4 ${ }^{+}$effector T cells [96]. In addition to IBD and mucosal immunity, $\operatorname{Tr} 1$ cells have been shown to play a key role in regulating allergic immune responses in a wide range experimental conditions (reviewed in [93]).

\section{Th3 Cells and the Role of TGF $\beta$ in iTreg Development}

Perhaps the most prominent factor in the conversion of naïve $\mathrm{CD} 4^{+} \mathrm{T}$ cells to iTregs is the cytokine TGF $\beta$. These iTregs, defined by some as Th3 cells, develop both in vitro and in vivo in the presence of TGF $\beta$. It is well established that antigen stimulation of naïve murine $\mathrm{CD} 4^{+} \mathrm{T}$ cells in vitro in the presence of TGF $\beta$ leads to the induction of Foxp3 expression and regulatory activity $[59,63,64]$. Furthermore, a substantial number of studies have demonstrated that TGF $\beta$ induces conversion of $\mathrm{CD} 4^{+} \mathrm{T}$ cells in vivo in both mice and humans. These iTregs are particularly important in a variety of disease settings and in maintaining tolerance to antigens expressed in the intestinal tissue, which has been described as a "privileged site" for iTreg differentiation [59,63,97-100]. Interestingly, the TGF $\beta$-dependent generation of iTregs can occur in mice that completely lack nTregs $[59,64,87]$, providing support that iTregs are developmentally distinct from nTregs.

TGF $\beta$-deficient mice succumb early on to spontaneous autoimmune disease [101]. Similarly, mice expressing a dominant-negative form of the TGFßRII manifest a similar, systemic disease, characterized by spontaneous $T$ cell activation and infiltration [19]. The importance of Tregs in mice lacking TGF $\beta$ was not fully appreciated prior to the discovery of TGF $\beta$ induced Treg formation. nTregs develop normally in TGF $\beta$-deficient mice, indicating production of TGF $\beta$ by nTregs is not required for suppression of inflammation [102]. Their maintenance and function in the periphery, however, is adversely affected in the absence of TGF $\beta$ [20]. The importance of TGF $\beta$-induced iTreg generation in controlling disease is evident from studies showing that $\mathrm{CD} 4^{+}$and $\mathrm{CD} 8^{+} \mathrm{T}$ cells from mice resistant to TGF $\beta$ signaling are unable to be controlled by Tregs upon transfer, resulting in IBD [103] and reduced tumor rejection [104], respectively. These data indicate that TGF $\beta$ plays pivotal roles in regulating tolerance via the maintenance and function of nTregs and by directly regulating conventional $\mathrm{T}$ cells.

As mentioned, a great deal of research in the iTreg field has focused on the mucosal tissues of the small intestine, as it has many features that make it a highly tolerogenic, and thus suitable, environment for iTreg formation. In particular, high concentrations of anti-inflammatory cytokines such as TGF $\beta$, IL-4 and IL-10, which increases the generation of both TGF $\beta$-induced Th3 and IL-10-induced Tr1 cells [54]. Recently, however, exciting new research had shed additional light on the mechanism of iTreg formation in the GALT, including factors that specifically promote the immune integrity of this highly antigenic environment. It has been known for some time that $\mathrm{T}$ cells express homing receptors that mediate migration into the gut, namely the integrin $\alpha 4 \beta 7$ and the chemokine receptor CCR9 [105,106]. Several groups have shown that these gut homing receptors are induced on $\mathrm{T}$ cells by a key metabolite of vitamin 
A, retinoic acid (RA), that is generated by DCs in the GALT [106]. Reduced numbers of T cells were found to home to the gut tissues in mice that were either deficient in vitamin A or retinoic acid receptor (RAR) signaling [106]. TGF $\beta$ produced by a variety of cells in the intestine also induces the up regulation of the integrin $\alpha \mathrm{E} \beta 7$ (CD103) on DCs, a population of cells that are particularly capable of producing RA $[76,80]$. Work by several groups has now shown that RA enhances the TGF $\beta$-dependent conversion of T cells into iTregs $[67,77,80]$.

Analysis of the cell types involved in iTreg conversion revealed that DCs derived from the spleen were unable to induce Foxp3 expression in naive T cells. However, DCs from the peyer's patches (PP), MLN and lamina propria (LP) of the gut could induce the generation of iTregs $[77,80]$. This induction correlated with CD103 expression, as CD103 ${ }^{+} \mathrm{DCs}$, but not CD103 ${ }^{-}$ DCs, were able to induce conversion, and required TGF $\beta$, as neutralizing anti-TGF $\beta$ antibodies blocked this process [80]. While RA alone was not able to induce conversion, inhibitors of retinol dehydrogenases greatly diminished the conversion process $[77,80]$. In addition, RA enhanced upregulation of $\alpha 4 \beta 7$ on the converted iTregs allowing them to home to the GALT more efficiently $[67,80,107]$. Lastly, RA was able to enhance the TGF $\beta$-dependent conversion of iTregs in vitro, which upon adoptive transfer in an IBD model, were able to suppress the induction of colitis more efficiently than TGF $\beta$ alone treated cells [76]. These data indicate that, at least in some disease models, the mechanisms by which Tregs develop and function may be a possible way to target Tregs for therapeutic benefit. While there is considerable overlap with regards to cytokine usage, perhaps additional tissue specific and/or environmental factors may also play a role in maintaining tolerance, similar to those found in the GALT.

\section{Role and Mechanisms of Treg Suppression in Disease}

How Tregs suppress has generated a tremendous amount of research effort since Tregs were identified [3]. There have been numerous manuscripts and reviews discussing and dissecting the mechanisms of suppression used by Tregs (see our previous reviews for a more in depth discussion of basic Treg mechanism: [14,108]). From these studies, it has become clear that Tregs do not rely on a single mechanism of suppression but rather have an arsenal of regulatory mechanisms at their disposal. These can be divided into four basic modes of action as depicted in Figure 2: inhibitory cytokines, cytolysis, metabolic disruption and modulation of APC function $[14,109,110]$. For the purpose of this review, we will provided a brief summary of the mechanisms of suppression utilized by Tregs followed by a more in depth analyses of studies that have contributed to our current knowledge of both the role and mechanisms of Tregmediated suppression in various key disease settings. The six types of disease states that we will focus on are inflammatory bowel disease (IBD), allergy and asthma, type I diabetes (TID), multiple sclerosis (MS), tumors and infections.

\section{Mechanisms of Treg Suppression}

The inhibitory cytokines IL-10, TGF $\beta$ and the recently described IL-35 areexpressed by Tregs and are considered a major mechanism of suppression utilized by Tregs. Interestingly, the concept of a soluble factor mediating Treg suppression is still controversial, considering the cell to cell contact dependence that was thought to be required to mediate suppression. However there is a growing list of in vivo studies describing the importance of Treg-derived IL-10, TGF $\beta$ and IL-35 in the suppression of various immune responses $[14,109,110]$.

Cytolysis by Tregs is mediated by granzyme A in humans and granzyme B in mice. While the dependence of perforin remains in question, it is clear that in both in vitro and in vivo models Tregs appear capable of killing target cells in a granzyme-dependent manner [111,112].

Recently, there have been several studies describing novel mechanisms of Treg suppression mediated through metabolic disruption. In these studies, the conventional T cells were 
suppressed by: (1) IL-2-deprivation mediated apoptosis, (2) the generation of pericellular adenosine by CD39 and CD73 and the subsequent activation of the adenosine receptor $2 \mathrm{~A}$ on conventional T cells, and (3) the transfer of the inhibitory second messenger cyclic AMP (cAMP) into conventional T cells via gap junctions [14,109,110].

Finally, Tregs can suppress target cells by augmenting APC function. This is primarily mediated through the interaction of cell surface molecules on Tregs such as CTLA-4 and the lymphocyte activation gene 3 (LAG-3) and their interaction with CD80/CD86 and MHC class II, respectively, on APCs $[14,109,110]$. This interaction results in the reduced ability of the APCs to activate conventional T cells. Additionally, there is evidence to suggest that Tregs can mediate the production of the immunoregulatory tryptophan-degrading enzyme, indoleamine 2,3-dioxygenase (IDO) by DCs [113]. Taken together, these mechanisms provide a potent arsenal for Tregs to utilize in maintaining peripheral tolerance and this is perhaps a reflection of the fact that Tregs need to suppress multiple cell types in a variety of distinct anatomical and disease settings.

\section{Inflammatory bowel disease}

IBD encompasses Crohn's disease and ulcerative colitis which manifests as chronic inflammation of the gastrointestinal tract. Disease susceptibility is governed by genetic and environmental factors. Individuals with IBD exhibit aberrant inflammation towards the normal bacterial flora in the gut. Several murine models, including DSS, TNBS and T cell-induced colitis, have been utilized to understanding the etiology and mechanisms underlying IBD. Among these murine models, the T cell transfer model is a well established system in which the role of Tregs in protection against IBD has been dissected. Therefore, for the purpose of this review we have mainly focused on the studies pertaining to the function of Tregs in mediating protection from IBD in this model. In the murine T cell transfer model, a small number of naïve $\mathrm{CD} 4^{+} \mathrm{CD} 45 \mathrm{RB}^{\text {hi }} \mathrm{T}$ cells are transferred into immunodeficient $\mathrm{Rag}^{-/-}$or scid mice which leads to Th1-mediated colitis in approximately $4-6$ weeks. This condition can be prevented or reversed by co transfer of Tregs or by adoptive transfer of Tregs once the pathology is established $[61,114]$. The majority of studies point to the cytokines IL-10 and TGF $\beta$ as key regulators used by Tregs to control IBD. In addition, CCR $4^{+}$and CCR $7^{+}$Tregs are found to be important in mediating the activity of Tregs at sites of inflammation in an IBD setting. Recently our lab has demonstrated a critical role for IL-35 in regulating IBD [115].

The importance of IL-10 in immunoregulation became evident upon analysis of $I l 10^{-/-}$mice, which develop enterocolitis [116]. However, under germ-free or Helicobacter-free conditions this does not occur, suggesting that IL-10 is important in controlling the inflammatory responses against certain commensal bacteria in the normal flora. Indeed, administration of rIL-10 can protect scid mice from colitis following transfer of $\mathrm{CD}^{+} \mathrm{CD} 45 \mathrm{RB}^{\text {hi }} \mathrm{T}$ cells in the absence of Tregs [117]. While these studies indicate a role for IL-10 in maintaining intestinal homeostasis, a direct link between IL-10 and Treg function was not provided until it was demonstrated that $\mathrm{CD} 4{ }^{+} \mathrm{CD} 45 \mathrm{RB}^{\text {lo }} \mathrm{T}$ cells isolated from $\mathrm{Ill0^{-/ }}$ mice failed to prevent IBD when co-transferred with $\mathrm{CD} 4{ }^{+} \mathrm{CD} 45 \mathrm{RB}^{\text {hi }}$ cells [118]. Moreover, the $\mathrm{CD} 4{ }^{+} \mathrm{CD} 45 \mathrm{RB}{ }^{\text {lo }} \mathrm{T}$ cells from $\mathrm{IllO}^{-/-}$mice induced inflammation in $\mathrm{Rag}^{-/-}$mice when administered alone. Consistent with these reports, treatment with anti-IL-10R antibody abolishes the protection mediated by Tregs in a T cell transfer model as well as in H.hepaticus-induced intestinal inflammation, suggesting a critical role for Treg-derived IL-10 in regulating intestinal inflammation. IL-10 produced by Tr1 cells does not appear to play a role in controlling inflammation as wild-type $\mathrm{CD}^{+} \mathrm{CD} 45 \mathrm{RB}^{\text {lo }} \mathrm{T}$ cells could protect against colitis induced by $1110^{-1-} \mathrm{CD} 4^{+}$effector $\mathrm{T}$ cells [119]. This suggested that differentiation of IL-10-induced Tr1 cells from CD4 ${ }^{+} \mathrm{CD}_{45 \mathrm{RB}^{\text {lo }}}$ effector $\mathrm{T}$ cells is not critical for the control of inflammation. This, however, does not exclude the possibility that IL-10 producing cells develop from the $\mathrm{CD} 4{ }^{+} \mathrm{CD} 45 \mathrm{RB}{ }^{\text {lo }}$ population. 
Although these studies provided evidence for a major role of IL-10 in the function of Tregs in IBD, treatment with anti-IL-10R antibody did not completely abolish the protection from colitis in CB-17-scid mice. In addition, $I l 10^{-/-} \mathrm{CD} 4^{+} \mathrm{CD} 25^{-} \mathrm{T}$ cells were also protective [119], thus providing contradictory evidence for the role of Treg-derived IL-10 in the regulation of inflammation. However, deletion of IL-10 specifically in Tregs shed insight into these contradictory data. Conditional IL-10 deletion in Tregs resulted in colonic inflammation. However, inflammation, onset and incidence of disease were less severe than that seen in the $I l 10^{-1-}$ mice [120]. These studies point to the fact that even though IL-10 derived from other cell types partially alleviate the symptoms, IL-10 derived from Tregs plays an important role in suppressing the local inflammation. This is consistent with evidence that in IBD, IL-10producing Tregs are selectively enriched in the colonic LP and secondary lymphoid organs [121]. Similarly in humans, Crohn's disease patients have intestinal $\mathrm{CD} 4^{+} \mathrm{T}$ cells that are defective in producing IL-10 [122].

IL-10, however, is not the sole player in the control of intestinal homeostasis. Other factors such as TGF $\beta$ and IL-35 also play a role. TGF $\beta$ deficient mice develop early multifocal inflammatory disease which leads to their death within $3-5$ weeks of age [123]. In the absence of T cell specific TGF $\beta$, mice develop colitis [101]. Tregs from these mice potentiated disease rather than cause protection in an IBD model [124]. Furthermore, anti-TGF $\beta$ neutralizing antibodies abrogate the ability of wild-type Tregs to mediate protection [125]. While it is clear that Treg-derived TGF $\beta$ is important in controlling colitis, there is evidence that TGF $\beta$ derived from other cells contributes to this protection. $\mathrm{CD} 4{ }^{+} \mathrm{CD} 25^{-} \mathrm{T}$ cells that express latency associated peptide (LAP) on the surface were found to suppress colitis induced by naïve T cells [126]. In addition, co-administration of $T g f b^{-/-}$Tregs with anti-TGF $\beta$ neutralizing antibody could not protect from naïve T cell induced colitis [103]. Finally, anti-TGF $\beta$ antibody was also shown to enhance colitis induced by $\mathrm{CD} 4{ }^{+} \mathrm{CD} 25^{-} \mathrm{T}$ cells [127]. Taken together, these reports suggest that Treg-derived TGF $\beta$, along with iTreg-derived TGF $\beta$ and additional gut-specific factors, play a critical role in IBD [128].

Recent work from our laboratory described a novel inhibitory cytokine, IL-35, that is preferentially expressed by Tregs and important for maximal Treg function [115,129]. IL-35 is a heterodimeric cytokine composed of Ebi3 and p35 chains and a new addition to the IL-12 family of cytokines. Tregs from either $\mathrm{Ebi3}^{-/-}$or $I l 12 \mathrm{a}^{-/-}$mice failed to cure IBD in $\mathrm{Rag}^{-/-}$ mice suggesting an important role for IL-35 in Treg-mediated protection from IBD [115]. Interestingly, initial studies with human Tregs suggest that EBI3 and hence IL-35 is not constitutively expressed in human Tregs [130]. However, further analysis is required to determine whether IL-35 is up regulated in human Tregs during an inflammatory response.

Taken together, it is apparent that IL-10, TGF $\beta$ and IL-35 are important mediators of suppression in Treg-mediated protection in IBD. It will be important to determine the relative contribution of each these cytokines in IBD in relation to one another. Furthermore, it remains unclear whether other Treg mechanisms play a role in Treg-mediated protection against IBD. In addition, they may ultimately form the basis of a future therapeutic modality.

\section{Allergy and Asthma}

The importance of Tregs in an airway hypersensitivity reaction (AHR) was clearly demonstrated in a study in which depletion of Tregs in allergen-sensitized mice resulted in increased levels of Th2 cytokines, IgE, and AHR [131]. In humans, Tregs from allergic donors have been found to be functionally defective in their ability to suppress the proliferation and IL-5 secretion of allergen-stimulated $\mathrm{CD}^{+}{ }^{+} \mathrm{T}$ cells compared to Tregs obtained from nonallergic donors [132]. In patients with atopic dermatitis, the functional defect does not reflect the reduction in numbers of Tregs [133]. However, children with asthma have fewer Tregs than the non-asthmatic patients [134]. Both nTregs and antigen-induced $\operatorname{Tr} 1$ cells have been 
implicated in controlling the allergen-induced Th2 response in mice and humans. The importance of IL-10 in protection against allergy became evident from human studies in which non-allergic individuals have a higher numbers of IL-10-producing activated T cells in response to IL-10 [135]. A role for Treg-derived IL-10 was clear when transfer of antigenspecific Tregs prior to allergen challenge inhibited allergic symptoms and Th2 cytokine production in an IL-10-dependent manner [136].

A role for TGF $\beta$ has also been described in allergic immune responses. Membrane bound TGF $\beta$ was found to be expressed in tolerized $\mathrm{CD} 4^{+} \mathrm{T}$ cells in response to respiratory antigens [137]. Consistent with the protection mediated by nTregs, iTregs inhibit the development of allergen-induced AHR [138]. Ovalbumin-specific T cells producing IL-10 [139] and TGF $\beta$ [140] could mediate protection against Th2-mediated AHR. In an antigen-dependent murine asthma model, adoptive transfer of Tregs over expressing TGF $\beta$ effectively suppressed AHR [141]. However, an indispensable role for Treg-derived IL-10 was evident as cells over expressing TGF $\beta$ but lacking IL-10 could not confer complete protection against AHR [141]. Similarly, from studies in humans it was noted that individuals with high doses of allergen exposure demonstrate a preferential switch towards IL-10-secreting Tr1 cells [142]. Another mechanism by which nTregs and $\operatorname{Tr} 1$ cells might be indirectly contributing to suppression of allergy is by inducing IgG4 and suppressing IgE production [143].

Due to importance of Treg-derived IL-10 and TGF $\beta$ in curtailing allergic conditions, Tregs represent an attractive cell type for therapeutic manipulation in these inflammatory diseases. Recent studies suggest that recombinant IL-2 in combination with anti-IL2 mAb reduces the severity of allergen-induced inflammation in the lung following expansion of Tregs ex vivo [144]. This outcome can be correlated to the increase in the Treg numbers seen following this treatment [145]. Collectively, these studies suggest that Tregs are important in regulating inflammatory conditions and that IL-10 and TGF $\beta$ produced by Tregs represent attractive candidates for therapeutic approaches. It should be noted that while IL-10 and TGF $\beta$ appear to be important contributors to Treg-mediated control of allergy and asthma, it remains unclear whether other Treg mechanisms can also control these inflammatory diseases.

\section{Type I Diabetes}

Accumulating evidence suggests that failure of suppression of autoreactive $\mathrm{T}$ cells by Tregs can result in autoimmune disorders such as type 1 diabetes (T1D) [146,147]. The Non Obese Diabetic (NOD) mouse is one of the best and most extensively studied spontaneous models of an autoimmune disease. Type 1 diabetes appears in female mice by 12-16 weeks of age and is preceded by a long phase of asymptomatic pre-diabetes characterized by progressive insulitis starting at 3 weeks of age. A protective role for Tregs in preventing spontaneous diabetes in NOD mice as well as diabetes induced by diabetogenic T cells has been established [148, 149]. First, the occurrence of diabetes in NOD mice is correlated with the reduced functional capacity of Tregs over time $[146,150]$. Additionally, the reduced susceptibility of conventional $\mathrm{T}$ cells to Treg-mediated suppression has been reported in diabetic humans [151] as well as in NOD mice [147]. Second, induction of disease by diabetogenic T cells in NOD.scid mice is prevented by co-injection of Tregs from young, pre-diabetic mice or islet-specific iTregs [152]. Lastly, depletion of Tregs in young NOD mice with anti-CD25 mAb also accelerates disease onset and increases incidence in both male and female mice [153]. The protection mediated by Tregs can be antigen-specific or non-specific. However, the suppression by islet antigen-specific Tregs, such as those derived from BDC.2.5 transgenic mouse, is more potent than that by the polyclonal Tregs as fewer are required to suppress the disease [154].

From NOD mouse models there is evidence that Tregs mediate their function in T1D through the action of CTLA- 4 and TGF $\beta$. The loss of activity of CTLA- 4 and TGF $\beta$ adversely affects the incidence and acceleration of T1D [147]. Additionally, a cocktail treatment of anti-CTLA-4 
and anti-TGF $\beta$ (but not anti-TNF $\alpha$ ) antibodies results in poly-autoimmune syndrome characterized by colitis, sialitis and gastritis [147]. Furthermore, $C d 28^{-/-}$NOD mice, which lack Tregs, exhibit an increased rate of T1D onset when treated with anti-CTLA- 4 and antiTGF $\beta$ [155]. It is unclear, however, if TGF $\beta$ from other cellular sources may be playing a role.

Therapies utilizing Tregs for treatment of T1D is an area of active investigation. Two different approaches have yielded promising results: induction of Tregs in vivo and adoptive transfer of in vitro cultured Tregs. Administration of non-mitogenic, CD3-specific antibodies in NOD mice induces a population of Foxp $3^{+}$Tregs that suppress T1D in a TGF $\beta$-dependent manner [152]. This has proved to be successful in clinical trials in humans where administration of hOKT3 $\gamma 1$ (Ala-Ala) (a humanized Fc mutated anti-CD3 monoclonal antibody), halted disease progression for more than one year $[156,157]$. Recently, treatment with rapamycin, which promotes the development of $\operatorname{Tr} 1$ cells and Foxp $3^{+}$Tregs, successfully prevented diabetes in mice [158]. Finally, ex vivo-expanded antigen-specific Tregs can suppress ongoing diabetes, providing a viable strategy for therapy [159].

\section{Multiple Sclerosis}

Multiple Sclerosis (MS), results from autoimmune destruction of the myelin sheath and inflammation of the brain and spinal cord [160]. The importance of Tregs in this disease has been suggested by studies in humans documenting the functional decline of Treg activity in MS patients [161]. The frequency or number of Tregs present in the periphery appears to be normal in MS patients [161-163] but the cells are not functional in vitro [162,164]. This reduced functional capacity is correlated with reduced Foxp3 protein levels [164]. Consistent with these reports, the presence of Tregs in the CNS is associated with recovery of MS while depletion of Foxp $3^{+}$Tregs exacerbates the disease [165]. The mouse model of MS, experimental autoimmune encephalomyelitis (EAE), shares many features with the human disease. Both show involvement of encephalitogenic myelin-specific $\mathrm{T}$ cells in the resulting pathology which consists of perivenular lesions in the CNS and extensive demyelination and axonal damage. In this model, adoptive transfer of polyclonal or antigen-specific Foxp $3^{+}$Tregs can prevent disease progression.

At present, IL-10 and TGF $\beta$ appear to be the primary mediators of Treg function in the cure of, or protection against, EAE. In an induced model of EAE, it was demonstrated that antiCD3-stimulated cells from naïve SJL mice secreted IL-10 and treatment with a soluble IL-10R antibody partially reversed the suppressive capacity of Tregs [166]. The primary evidence for a role for IL-10 in in vivo protection against EAE has been derived from adoptive transfer studies where wild type but not $I l 10^{-/-}$Tregs from unimmunized SJL/J donors partially protected recipient mice from PLP $_{139-151}$-induced EAE [166]. In support of this, disruption of the $I l 10$ or $I l 10 r$ gene in mice resulted in failure to inhibit MOG peptide-induced EAE suggesting that IL-10 is important in mediating protection against EAE [167]. Additionally, it has been demonstrated that there is a significant accumulation of IL-10-producing Tregs in the CNS which correlated with the recovery phase. These cells expressed Foxp3 and could mediate suppressive activity in vitro [165]. Histological and flow cytometric analysis by several groups have also revealed that the Tregs localize to the CNS during inflammation $[168,169]$.

The importance of TGF $\beta$ in recovery from EAE was demonstrated in two independent studies. First, it was demonstrated that the percentage of $\mathrm{CD}^{+}{ }^{+}$cells expressing TGF $\beta$ LAP on the cell surface increased significantly in blood and spleen of EAE-recovered mice as compared with the naïve mice [170]. Second, in vivo neutralization of TGF $\beta$ prevented recovery from disease [170]. Recently it was found that $\mathrm{CD} 4^{+} \mathrm{CD} 25^{+} \mathrm{LAP}^{+}$cells suppress MOG-specific immune responses in a TGF $\beta$-dependent manner by inducing Foxp3 and by inhibiting IL-17 production [171]. Therapeutic approaches focusing on enhancing Treg number or function for protection from EAE may be of great benefit to patients suffering from MS. Recently, genetically modified 
polyclonal Tregs expressing a chimeric receptor consisting of an MBP epitope bound to the extracellular and transmembrane domain of the $\mathrm{CD} 3 \zeta$ chain results in functional Treg activation upon encounter with the MBP specific autoreactive T cells. These receptor-modified Tregs inhibited the onset as well as the progression of EAE in an antigen-specific manner [172].

\section{Tumors}

The primary objective of Tregs is to maintain peripheral tolerance which involves policing and preventing anti-self reactivity. However, tumors are seen as self and thus Tregs try to prevent anti-tumor specific $\mathrm{T}$ cells from clearing the tumor, making Tregs a significant barrier for effective immunotherapy. Both the adaptive and innate immune responses are important in tumor clearance. If Tregs are capable of suppressing the beneficial anti-tumor response, they should be present in the tumor environment. Indeed, there are numerous publications that report an increase in the number of Tregs in the local tumor environment of humans suffering from melanoma [173], lymphoma [174], and ovarian [175-177], pancreatic [178], breast [178], gastric $[179,180]$, and lung $[175,181]$ cancers. However, there are conflicting reports as to whether the presence of Tregs in the local tumor environment is indicative of a poor prognosis $[176,177]$ or a positive prognosis [182-184]. Therefore, further analysis is required to correlate prognosis with Treg frequencies in humans. While it is difficult to discern these discrepancies, it is worth noting that in these studies the presence of Tregs was determined by staining for Foxp3, which does not necessarily correlate with human Tregs as it as been shown that human conventional T cells can express Foxp3 following activation [185-187]. A recent paper clearly demonstrates that the Foxp $3^{+}$tumor infiltrating T cells were Tregs by both staining and functional analysis [176]. Importantly, they found that the presence of Tregs correlated with a poor prognosis. In murine tumor models, there is strong evidence to suggest that in the absence of Tregs a proper antitumor response can be mounted resulting in the clearance of the tumor. The original studies to demonstrate this were done by depleting the Tregs in vivo with antiCD25 depleting antibodies [188,189]. Together, the data generated with human cells and murine models strongly suggests a role for Tregs in suppressing the anti-tumor response.

There are a number of studies that have attempted determine what mechanism Tregs yse to suppress the anti-tumor response, with the majority focusing on the inhibitory cytokines TGF $\beta$ and IL-10. It was initially demonstrated in both humans and mice that Tregs are capable of suppressing both adaptive and innate aspects of the anti-tumor immune response in a TGF $\beta$-dependent manner by suppressing $\mathrm{CD} 8^{+} \mathrm{T}$ cells and NK cells, two of the immune system's primary weapons against tumors [104,190]. More recently in a murine tumor model, an effective anti-tumor response could be generated by blocking Treg function with a novel peptide inhibitor that bound TGF $\beta$ on the cell surface of Tregs suggesting a direct role of TGF $\beta$ in the anti-tumor response [191]. Together with TGF $\beta$, it was demonstrated that the potent inhibitor cytokine IL-10, was important in the Treg suppressive response in a UVinduced tumor model using IL-10 deficient mice [192]. The reliance of Tregs on IL-10 to suppress an anti-tumor response in humans was also observed in an early study involving Tregs isolated from head and neck squamous cell carcinoma [193]. Although the data was generated in vitro, it was clear that in humans, Tregs are capable of suppressing the anti-tumor response in an IL-10/TGF $\beta$-dependent manner. Taken together there is convincing evidence to suggest that the suppressive cytokines IL-10 and TGF $\beta$ are important mechanisms by which Treg mediate suppression within the tumor microenvironment of patients and murine tumor models.

Interestingly, Tregs may also augment APC function in a suppressive cytokine-dependent manner. Studies with human Tregs, describe a novel interaction between IL-10-producing Tregs and APCs in which IL-10 causes the up-regulation of B7H4 on APCs rendering them immunosuppressive [194]. This was followed by a subsequent paper that showed that B7- 
$\mathrm{H} 4^{+}$tumor infiltrating macrophages were immunosuppressive in a human ovarian carcinoma [195]. These papers provide evidence for a cytokine-driven, APC altering mechanism by which IL-10 produced by Tregs renders APCs immunosuppressive in the tumor environment.

Another mechanism in the Treg arsenal is the suppression of APC function via direct contact within the local tumor microenvironment resulting in the reduction of APC-mediated activation events. In a recent paper, CTLA-4 on Tregs mediated the downregulation of CD80 (B7.1) and CD86 (B7.2) on APCs thereby affecting the ability of the APCs to activate other T cells by reducing CD28 co-stimulation. This Treg-mediated CTLA-4/APC interaction was important in suppressing the anti-tumor response, as a robust anti-tumor response was mounted in the presence of CTLA-4 deficient Tregs compared to wild type Tregs [196]. Additionally, there is evidence to suggest that Tregs interact with APCs through CTLA4 and cause the APCs to up regulate production of the tryptophan-degrading enzyme, indoleamine 2,3-dioxygenase (IDO) which is a potent immunoregulatory enzyme [197]. Interestingly, IDO-producing pDCs isolated from tumor draining lymph nodes activate Tregs which cause the upregulation of the programmed cell death ligand 1 (PD-L1) and PD-L2 expression on target DCs resulting in the suppression of the effector T cell response [198]. Additionally, this could also lead to a feedback mechanism in which Tregs, through CTLA-4 interaction with DCs, cause an increase in IDO production $[113,199]$ and subsequently an increase in the number of $\mathrm{IDO}^{+} \mathrm{pDCs}$ which could in turn activate Tregs.

The primary method of tumor clearance is granzyme B-dependent cytolysis mediated by $\mathrm{CD} 8^{+} \mathrm{T}$ cells and NK cells. It was initially demonstrated that Tregs can also kill conventional $\mathrm{T}$ cells in a granzyme B-dependent, perforin-independent pathway [111]. Subsequently, it was shown that granzyme B was upregulated in Tregs in the tumor environment and that, in the presence of granzyme B-deficient Tregs, an active tumor response was generated and the tumor cleared [112]. These data suggest that Tregs can suppress the anti-tumor response via a cytolysis-mediated event.

Taken together, it is apparent that Tregs utilize a variety of mechanisms to suppress the beneficial anti-tumor response. While it is clear that suppressive cytokines are an important part of the Treg arsenal, Tregs also suppress APC function as well as kill their targets in a granzyme B-dependent manner. Interestingly, the tumor environment is the only disease state in which Tregs have been shown to utilize their cytolytic capabilities to control the immune response. It is important to note, that this was demonstrated in murine models and further studies are required to determine if it is the same in humans. However, cytolysis does represent a potentially novel mechanism to target Tregs in a-disease specific manner.

\section{Infections}

It is clear that Tregs play a significant role in the immune response to infections as well as the clearance of the invading pathogen. This has been demonstrated in both humans and murine models [200]. In particular, the importance of Tregs has been shown in parasitic, fungal and bacterial infections such as Leishmania major [201], Plasmodium yoelii [202], Candida albicans [203], Listeria monocytogenes [204] and Mycobacterium tuberculosis [205,206]. Viral clearance is also altered by the presence of Tregs. This has been seen during infection with herpes simplex virus (HSV) [207,208], hepatitis B and C virus [209,210], cytomegalovirus (CMV) [211] and human immunodeficiency virus [212,213].

The consequences of Treg mediated suppression of the immune response during infection are controversial. There are studies that suggest Tregs, while limiting local tissue damage, prevent sterilizing immunity against the pathogen and thus allow for a persistent infection [201,214]. In turn this persistent infection results in protective immunity against a subsequent challenge with the pathogen [201]. While this 'symbiotic relationship' may be beneficial to the host, there 
is also evidence to suggest that Tregs can be detrimental to the host. For instance, Treg suppression of the immune response to Plasmodium yoelli allows the parasite to escape clearance [202]. In support of this, sterilizing immunity in a Leishmania major model can be achieved by depletion of Tregs [201]. However, depletion of Tregs may not always be beneficial to the host, as a recent study suggests that Tregs are critical in the early stages of infection by HSV and depletion of Tregs accelerated the time to death as well as caused an increase in viral loads [215].

The mechanisms by which Tregs suppress or alter the immune response against viral, parasitic, fungal and bacterial infections is still unclear [216]. This is primarily clouded by the fact that the immune response to foreign antigens results in the production of a milieu of cytokines and inhibitory factors, especially IL-10 and TGF $\beta$. While it has been demonstrated that the majority of inhibition of the immune response generated against certain pathogens may be mediated by IL-10, this is not necessarily produced by Tregs [205,217]. However, there is some evidence to suggest that TGF $\beta$ may be an important cytokine utilized by Tregs in the suppression of the immune response against Mycobacterium tuberculosis [205].

It is clear that there is a need for further analysis to understand the mechanisms involved in Treg-mediated suppression of effective anti-pathogen responses in humans. As the immune system is under constant assault from pathogens, infection is the most common of all disease states. Infection is also the only disease state in which Treg activity can be both deleterious, because it prevents sterilizing immunity, and helpful, by limiting rampant immune responses that could be harmful to the surrounding tissue. Therefore, it is possible that Tregs utilize all mechanisms at their disposal to achieve a balanced immune response so that proper pathogen clearance can be achieved. Understanding the mechanisms and determining if certain mechanisms are over utilized in certain infections may help in the development of effective treatment and immunization strategies against a wide variety of infectious agents.

\section{Summary}

Since the discovery of suppressor $\mathrm{T}$ cells, and their subsequent 'reinvention' as regulatory $\mathrm{T}$ cells, research has firmly established a role for Tregs in controlling immune homeostasis and modulating a wide variety of disease states. While a great deal of progress has been made in understanding the development and mechanisms of suppression of both nTregs and iTregs, there remain a number of questions that need to be addressed. First, while it is clear there are several mechanisms used by Tregs to mediate their suppression, it remains to be determined if additional mechanisms are used and whether any new or previously described mechanism may be specific to a particular disease state. Second, while the analysis of Tregs in murine models have been indispensible in characterizing their role in immune homeostasis, tolerance and a variety of diseases, it is clear that additional research needs to be performed on human Tregs, particularly with regard to specific markers with which to isolate and study them. Answering these questions will not only bring us closer to understanding how this unique population of cells develop and function, but also how to exploit or mitigate their suppressive activity for targeted therapy against a wide variety of diseases.

\section{References}

1. Gershon RK. A disquisition on suppressor T cells. Transplant.Rev 1975;26:170-185. [PubMed: 1101469]

2. Gershon RK, Cohen P, Hencin R, Liebhaber SA. Suppressor T cells. Journal of Immunology 1972;108:586-590.

3. Sakaguchi S, Sakaguchi N, Asano M, Itoh M, Toda M. Immunologic self-tolerance maintained by activated T cells expressing IL-2 receptor alpha-chains (CD25). Breakdown of a single mechanism of 
self-tolerance causes various autoimmune diseases. The Journal of Immunology 1995; 155:1151-1164. [PubMed: 7636184]

4. Hori S, Nomura T, Sakaguchi S. Control of regulatory T cell development by the transcription factor Foxp3. Science 2003;299:1057-1061. [PubMed: 12522256]

5. Fontenot JD, Gavin MA, Rudensky AY. Foxp3 programs the development and function of CD4+CD25 + regulatory T cells. Nat Immunol 2003;4:330-336. [PubMed: 12612578]

6. Khattri R, Cox T, Yasayko SA, Ramsdell F. An essential role for Scurfin in CD4+CD25+ T regulatory cells. Nat Immunol 2003;4:337-342. [PubMed: 12612581]

7. Bennett CL, Christie J, Ramsdell F, Brunkow ME, Ferguson PJ, Whitesell L, Kelly TE, Saulsbury FT, Chance PF, Ochs HD. The immune dysregulation, polyendocrinopathy, enteropathy, X-linked syndrome (IPEX) is caused by mutations of FOXP3. Nat Genet 2001;27:20-21. [PubMed: 11137993]

8. Gambineri E, Torgerson TR, Ochs HD. Immune dysregulation, polyendocrinopathy, enteropathy, and X-linked inheritance (IPEX), a syndrome of systemic autoimmunity caused by mutations of FOXP3, a critical regulator of T-cell homeostasis. Curr Opin Rheumatol 2003;15:430-435. [PubMed: 12819471]

9. Sakaguchi S. Naturally arising CD4+ regulatory t cells for immunologic self-tolerance and negative control of immune responses. Annu Rev Immunol 2004;22:531-562. [PubMed: 15032588]

10. Asano M, Toda M, Sakaguchi N, Sakaguchi S. Autoimmune disease as a consequence of developmental abnormality of a T cell subpopulation. J Exp Med 1996;184:387-396. [PubMed: 8760792]

11. Liu W, Putnam AL, Xu-Yu Z, Szot GL, Lee MR, Zhu S, Gottlieb PA, Kapranov P, Gingeras TR, Fazekas de St Groth B, Clayberger C, Soper DM, Ziegler SF, Bluestone JA. CD127 expression inversely correlates with FoxP3 and suppressive function of human CD4+ T reg cells. J Exp Med 2006;203:1701-1711. [PubMed: 16818678]

12. Paust S, Lu L, McCarty N, Cantor H. Engagement of B7 on effector T cells by regulatory T cells prevents autoimmune disease. Proc Natl Acad Sci U S A 2004;101:10398-10403. [PubMed: 15235129]

13. Ndhlovu LC, Takeda I, Sugamura K, Ishii N. Expanding role of T-cell costimulators in regulatory Tcell function: recent advances in accessory molecules expressed on both regulatory and nonregulatory T cells. Crit Rev Immunol 2004;24:251-266. [PubMed: 15588225]

14. Vignali DA, Collison LW, Workman CJ. How regulatory T cells work. Nat.Rev.Immunol 2008;8:523-532. [PubMed: 18566595]

15. Ziegler SF. FOXP3: of mice and men. Annu Rev Immunol 2006;24:209-226. [PubMed: 16551248]

16. Keir ME, Sharpe AH. The B7/CD28 costimulatory family in autoimmunity. Immunol Rev 2005;204:128-143. [PubMed: 15790355]

17. Malek TR, Yu A, Vincek V, Scibelli P, Kong L. CD4 regulatory T cells prevent lethal autoimmunity in IL-2Rbeta-deficient mice. Implications for the nonredundant function of IL-2. Immunity 2002;17:167-178. [PubMed: 12196288]

18. Su L, Creusot RJ, Gallo EM, Chan SM, Utz PJ, Fathman CG, Ermann J. Murine CD4+CD25+ regulatory $\mathrm{T}$ cells fail to undergo chromatin remodeling across the proximal promoter region of the IL-2 gene. J Immunol 2004;173:4994-5001. [PubMed: 15470042]

19. Gorelik L, Flavell RA. Abrogation of TGFbeta signaling in T cells leads to spontaneous T cell differentiation and autoimmune disease. Immunity 2000;12:171-181. [PubMed: 10714683]

20. Marie JC, Letterio JJ, Gavin M, Rudensky AY. TGF-beta1 maintains suppressor function and Foxp3 expression in CD4+CD25+ regulatory T cells. J Exp Med 2005;201:1061-1067. [PubMed: 15809351]

21. Hogquist KA, Baldwin TA, Jameson SC. Central tolerance: learning self-control in the thymus. Nat Rev Immunol 2005;5:772-782. [PubMed: 16200080]

22. Kronenberg M, Rudensky A. Regulation of immunity by self-reactive T cells. Nature 2005;435:598604. [PubMed: 15931212]

23. Jordan MS, Boesteanu A, Reed AJ, Petrone AL, Holenbeck AE, Lerman MA, Naji A, Caton AJ. Thymic selection of CD4+CD25+ regulatory T cells induced by an agonist self-peptide. Nat Immunol 2001;2:301-306. [PubMed: 11276200] 
24. Pacholczyk R, Ignatowicz H, Kraj P, Ignatowicz L. Origin and T cell receptor diversity of Foxp3 +CD4+CD25+ T cells. Immunity 2006;25:249-259. [PubMed: 16879995]

25. Pacholczyk R, Kern J, Singh N, Iwashima M, Kraj P, Ignatowicz L. Nonself-antigens are the cognate specificities of Foxp3+ regulatory T cells. Immunity 2007;27:493-504. [PubMed: 17869133]

26. Takahashi M, Nakamura K, Honda K, Kitamura Y, Mizutani T, Araki Y, Kabemura T, Chijiiwa Y, Harada N, Nawata $\mathrm{H}$. An inverse correlation of human peripheral blood regulatory $\mathrm{T}$ cell frequency with the disease activity of ulcerative colitis. Dig Dis Sci 2006;51:677-686. [PubMed: 16614988]

27. Thornton AM, Shevach EM. Suppressor effector function of CD4+CD25+ immunoregulatory T cells is antigen nonspecific. J Immunol 2000;164:183-190. [PubMed: 10605010]

28. Takahashi T, Kuniyasu Y, Toda M, Sakaguchi N, Itoh M, Iwata M, Shimizu J, Sakaguchi S. Immunologic self-tolerance maintained by CD25+CD4+ naturally anergic and suppressive T cells: induction of autoimmune disease by breaking their anergic/suppressive state. Int Immunol 1998;10:1969-1980. [PubMed: 9885918]

29. Szymczak-Workman AL, Workman CJ, Vignali DAA. Cutting edge: Regulatory T cells do not require stimulation through their T cell receptor to suppress. J Immunol. 2009(in press).

30. Hsieh CS, Liang Y, Tyznik AJ, Self SG, Liggitt D, Rudensky AY. Recognition of the peripheral self by naturally arising CD25+ CD4+ T cell receptors. Immunity 2004;21:267-277. [PubMed: 15308106]

31. Picca CC, Caton AJ. The role of self-peptides in the development of CD4+ CD25+ regulatory T cells. Curr Opin Immunol 2005;17:131-136. [PubMed: 15766671]

32. Pacholczyk R, Kraj P, Ignatowicz L. Peptide specificity of thymic selection of CD4+CD25+ T cells. J Immunol 2002;168:613-620. [PubMed: 11777953]

33. Pennington DJ, Silva-Santos B, Silberzahn T, Escorcio-Correia M, Woodward MJ, Roberts SJ, Smith AL, Dyson PJ, Hayday AC. Early events in the thymus affect the balance of effector and regulatory T cells. Nature 2006;444:1073-1077. [PubMed: 17190001]

34. van Santen HM, Benoist C, Mathis D. Number of T reg cells that differentiate does not increase upon encounter of agonist ligand on thymic epithelial cells. J Exp Med 2004;200:1221-1230. [PubMed: 15534371]

35. Anderson MS, Venanzi ES, Klein L, Chen Z, Berzins SP, Turley SJ, von Boehmer H, Bronson R, Dierich A, Benoist C, Mathis D. Projection of an immunological self shadow within the thymus by the aire protein. Science 2002;298:1395-1401. [PubMed: 12376594]

36. Kyewski B, Klein L. A central role for central tolerance. Annu Rev Immunol 2006;24:571-606. [PubMed: 16551260]

37. Aschenbrenner K, D'Cruz LM, Vollmann EH, Hinterberger M, Emmerich J, Swee LK, Rolink A, Klein L. Selection of Foxp3+ regulatory T cells specific for self antigen expressed and presented by Aire+ medullary thymic epithelial cells. Nat Immunol 2007;8:351-358. [PubMed: 17322887]

38. Gavin MA, Rasmussen JP, Fontenot JD, Vasta V, Manganiello VC, Beavo JA, Rudensky AY. Foxp3dependent programme of regulatory T-cell differentiation. Nature 2007;445:771-775. [PubMed: 17220874]

39. Lin W, Haribhai D, Relland LM, Truong N, Carlson MR, Williams CB, Chatila TA. Regulatory T cell development in the absence of functional Foxp3. Nat Immunol 2007;8:359-368. [PubMed: 17273171]

40. Anderson MS, Venanzi ES, Chen Z, Berzins SP, Benoist C, Mathis D. The cellular mechanism of Aire control of T cell tolerance. Immunity 2005;23:227-239. [PubMed: 16111640]

41. Kuroda N, Mitani T, Takeda N, Ishimaru N, Arakaki R, Hayashi Y, Bando Y, Izumi K, Takahashi T, Nomura T, Sakaguchi S, Ueno T, Takahama Y, Uchida D, Sun S, Kajiura F, Mouri Y, Han H, Matsushima A, Yamada G, Matsumoto M. Development of autoimmunity against transcriptionally unrepressed target antigen in the thymus of Aire-deficient mice. J Immunol 2005;174:1862-1870. [PubMed: 15699112]

42. Fontenot JD, Rasmussen JP, Gavin MA, Rudensky AY. A function for interleukin 2 in Foxp3expressing regulatory T cells. Nat Immunol 2005;6:1142-1151. [PubMed: 16227984]

43. Watanabe N, Wang YH, Lee HK, Ito T, Cao W, Liu YJ. Hassall's corpuscles instruct dendritic cells to induce CD4+CD25+ regulatory T cells in human thymus. Nature 2005;436:1181-1185. [PubMed: 16121185] 
44. Kurobe H, Liu C, Ueno T, Saito F, Ohigashi I, Seach N, Arakaki R, Hayashi Y, Kitagawa T, Lipp M, Boyd RL, Takahama Y. CCR7-dependent cortex-to-medulla migration of positively selected thymocytes is essential for establishing central tolerance. Immunity 2006;24:165-177. [PubMed: 16473829]

45. Liston A, Nutsch KM, Farr AG, Lund JM, Rasmussen JP, Koni PA, Rudensky AY. Differentiation of regulatory Foxp3+ T cells in the thymic cortex. Proc Natl Acad Sci U S A 2008;105:11903-11908. [PubMed: 18695219]

46. Lio CW, Hsieh CS. A two-step process for thymic regulatory T cell development. Immunity 2008;28:100-111. [PubMed: 18199417]

47. Marie JC, Liggitt D, Rudensky AY. Cellular mechanisms of fatal early-onset autoimmunity in mice with the T cell-specific targeting of transforming growth factor-beta receptor. Immunity 2006;25:441-454. [PubMed: 16973387]

48. Sempowski GD, Cross SJ, Heinly CS, Scearce RM, Haynes BF. CD7 and CD28 are required for murine $\mathrm{CD} 4+\mathrm{CD} 25+$ regulatory $\mathrm{T}$ cell homeostasis and prevention of thyroiditis. J Immunol 2004;172:787-794. [PubMed: 14707048]

49. Tang Q, Henriksen KJ, Boden EK, Tooley AJ, Ye J, Subudhi SK, Zheng XX, Strom TB, Bluestone JA. Cutting edge: CD28 controls peripheral homeostasis of CD4+CD25+ regulatory T cells. J Immunol 2003;171:3348-3352. [PubMed: 14500627]

50. Vella A, Cooper JD, Lowe CE, Walker N, Nutland S, Widmer B, Jones R, Ring SM, McArdle W, Pembrey ME, Strachan DP, Dunger DB, Twells RC, Clayton DG, Todd JA. Localization of a type 1 diabetes locus in the IL2RA/CD25 region by use of tag single-nucleotide polymorphisms. Am J Hum Genet 2005;76:773-779. [PubMed: 15776395]

51. Bayer AL, Yu A, Adeegbe D, Malek TR. Essential role for interleukin-2 for CD4(+)CD25(+) T regulatory cell development during the neonatal period. J Exp Med 2005;201:769-777. [PubMed: 15753210]

52. Sakaguchi S. Naturally arising Foxp3-expressing CD25+CD4+ regulatory T cells in immunological tolerance to self and non-self. Nat Immunol 2005;6:345-352. [PubMed: 15785760]

53. Bluestone JA, Abbas AK. Natural versus adaptive regulatory T cells. Nat Rev.Immunol 2003;3:253257. [PubMed: 12658273]

54. Groux H, O'Garra A, Bigler M, Rouleau M, Antonenko S, de Vries JE, Roncarolo MG. A CD4+ Tcell subset inhibits antigen-specific T-cell responses and prevents colitis. Nature 1997;389:737-742. [PubMed: 9338786]

55. Vieira PL, Christensen JR, Minaee S, O'Neill EJ, Barrat FJ, Boonstra A, Barthlott T, Stockinger B, Wraith DC, O'Garra A. IL-10-secreting regulatory T cells do not express Foxp3 but have comparable regulatory function to naturally occurring CD4+CD25+ regulatory T cells. The Journal of Immunology 2004;172:5986-5993. [PubMed: 15128781]

56. Weiner HL. Induction and mechanism of action of transforming growth factor-beta-secreting Th3 regulatory cells. Immunol Rev 2001;182:207-214. [PubMed: 11722636]

57. Skapenko A, Kalden JR, Lipsky PE, Schulze-Koops H. The IL-4 receptor alpha-chain-binding cytokines, IL-4 and IL-13, induce forkhead box P3-expressing CD25+CD4+ regulatory T cells from CD25-CD4+ precursors. J Immunol 2005;175:6107-6116. [PubMed: 16237107]

58. Zheng SG. The Critical Role of TGF-beta1 in the Development of Induced Foxp3+ Regulatory T Cells. Int.J Clin.Exp.Med 2008;1:192-202. [PubMed: 19079658]

59. Chen W, Jin W, Hardegen N, Lei Kj, Li L, Marinos N, McGrady G, Wahl SM. Conversion of

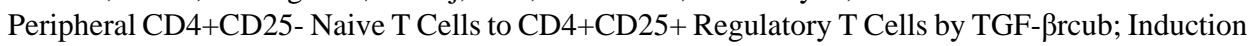
of Transcription Factor Foxp3. The Journal of Experimental Medicine 2003;198:1875-1886. [PubMed: 14676299]

60. Kohm AP, Carpentier PA, Anger HA, Miller SD. Cutting Edge: CD4+CD25+ Regulatory T Cells Suppress Antigen-Specific Autoreactive Immune Responses and Central Nervous System Inflammation During Active Experimental Autoimmune Encephalomyelitis. The Journal of Immunology 2002;169:4712-4716. [PubMed: 12391178]

61. Maloy KJ, Salaun L, Cahill R, Dougan G, Saunders NJ, Powrie F. CD4+CD25+ T(R) cells suppress innate immune pathology through cytokine-dependent mechanisms. J Exp Med 2003;197:111-119. [PubMed: 12515818] 
62. Zheng SG, Wang JH, Koss MN, Quismorio F Jr, Gray JD, Horwitz DA. CD4+ and CD8+ Regulatory T Cells Generated Ex Vivo with IL-2 and TGF- $\beta$ Suppress a Stimulatory Graft-versus-Host Disease with a Lupus-Like Syndrome. The Journal of Immunology 2004;172:1531-1539. [PubMed: 14734731]

63. Apostolou I, von Boehmer H. In Vivo Instruction of Suppressor Commitment in Naive T Cells. The Journal of Experimental Medicine 2004;199:1401-1408. [PubMed: 15148338]

64. Kretschmer K, Apostolou I, Hawiger D, Khazaie K, Nussenzweig MC, von Boehmer H. Inducing and expanding regulatory T cell populations by foreign antigen. Nat Immunol 2005;6:1219-1227. [PubMed: 16244650]

65. Apostolou I, Sarukhan A, Klein L, von Boehmer H. Origin of regulatory T cells with known specificity for antigen. Nat Immunol 2002;3:756-763. [PubMed: 12089509]

66. Taylor PA, Lees CJ, Blazar BR. The infusion of ex vivo activated and expanded CD4(+)CD25(+) immune regulatory cells inhibits graft-versus-host disease lethality. Blood 2002;99:3493-3499. [PubMed: 11986199]

67. Benson MJ, Pino-Lagos K, Rosemblatt M, Noelle RJ. All-trans retinoic acid mediates enhanced T reg cell growth, differentiation, and gut homing in the face of high levels of co-stimulation. J Exp.Med 2007;204:1765-1774. [PubMed: 17620363]

68. Floess S, Freyer J, Siewert C, Baron U, Olek S, Polansky J, Schlawe K, Chang HD, Bopp T, Schmitt E, Klein-Hessling S, Serfling E, Hamann A, Huehn J. Epigenetic control of the foxp3 locus in regulatory T cells. PLoS.Biol 2007;5:e38. [PubMed: 17298177]

69. Steinbrink K, Graulich E, Kubsch S, Knop J, Enk AH. CD4(+) and CD8(+) anergic T cells induced by interleukin-10-treated human dendritic cells display antigen-specific suppressor activity. Blood 2002;99:2468-2476. [PubMed: 11895781]

70. Verhasselt V, Vosters O, Beuneu C, Nicaise C, Stordeur P, Goldman M. Induction of FOXP3expressing regulatory CD4pos $\mathrm{T}$ cells by human mature autologous dendritic cells. Eur.J Immunol 2004;34:762-772. [PubMed: 14991606]

71. Masuyama J, Kaga S, Kano S, Minota S. A novel costimulation pathway via the 4C8 antigen for the induction of CD4+ regulatory T cells. J Immunol 2002;169:3710-3716. [PubMed: 12244164]

72. Grundstrom S, Cederbom L, Sundstedt A, Scheipers P, Ivars F. Superantigen-induced regulatory T cells display different suppressive functions in the presence or absence of natural CD4+CD25+ regulatory T cells in vivo. J Immunol 2003;170:5008-5017. [PubMed: 12734345]

73. Walker MR, Kasprowicz DJ, Gersuk VH, Benard A, Van Landeghen M, Buckner JH, Ziegler SF. Induction of FoxP3 and acquisition of T regulatory activity by stimulated human CD4+CD25- T cells. J Clin Invest 2003;112:1437-1443. [PubMed: 14597769]

74. Levings MK, Sangregorio R, Galbiati F, Squadrone S, de Waal Malefyt R, Roncarolo MG. IFN-alpha and IL-10 induce the differentiation of human type 1 T regulatory cells. J Immunol 2001;166:55305539. [PubMed: 11313392]

75. Kemper C, Chan AC, Green JM, Brett KA, Murphy KM, Atkinson JP. Activation of human CD4+ cells with CD3 and CD46 induces a T-regulatory cell 1 phenotype. Nature 2003;421:388-392. [PubMed: 12540904]

76. Mucida D, Park Y, Kim G, Turovskaya O, Scott I, Kronenberg M, Cheroutre H. Reciprocal TH17 and Regulatory T Cell Differentiation Mediated by Retinoic Acid. Science 2007;317:256-260. [PubMed: 17569825]

77. Sun CM, Hall JA, Blank RB, Bouladoux N, Oukka M, Mora JR, Belkaid Y. Small intestine lamina propria dendritic cells promote de novo generation of Foxp3 $\mathrm{T}$ reg cells via retinoic acid. The Journal of Experimental Medicine 2007;204:1775-1785. [PubMed: 17620362]

78. Moseman EA, Liang X, Dawson AJ, Panoskaltsis-Mortari A, Krieg AM, Liu YJ, Blazar BR, Chen W. Human plasmacytoid dendritic cells activated by $\mathrm{CpG}$ oligodeoxynucleotides induce the generation of CD4+CD25+ regulatory T cells. Journal of Immunology 2004;173:4433-4442.

79. Verginis P, Li HS, Carayanniotis G. Tolerogenic semimature dendritic cells suppress experimental autoimmune thyroiditis by activation of thyroglobulin-specific CD4+CD25+ T cells. The Journal of Immunology 2005;174:7433-7439. [PubMed: 15905592]

80. Coombes JL, Siddiqui KRR, rancibia-Carcamo CV, Hall J, Sun CM, Belkaid Y, Powrie F. A functionally specialized population of mucosal CD103+ DCs induces Foxp3+ regulatory T cells via 
a TGF- $\beta$ and retinoic acid dependent mechanism. The Journal of Experimental Medicine 2007;204:1757-1764. [PubMed: 17620361]

81. Ghiringhelli F, Puig PE, Roux S, Parcellier A, Schmitt E, Solary E, Kroemer G, Martin F, Chauffert B, Zitvogel L. Tumor cells convert immature myeloid dendritic cells into TGF- $\beta$-secreting cells inducing CD4+CD25+ regulatory T cell proliferation. The Journal of Experimental Medicine 2005;202:919-929. [PubMed: 16186184]

82. Min WP, Zhou D, Ichim TE, Strejan GH, Xia X, Yang J, Huang X, Garcia B, White D, Dutartre P, Jevnikar AM, Zhong R. Inhibitory Feedback Loop Between Tolerogenic Dendritic Cells and Regulatory T Cells in Transplant Tolerance. The Journal of Immunology 2003;170:1304-1312. [PubMed: 12538690]

83. Denning TL, Wang YC, Patel SR, Williams IR, Pulendran B. Lamina propria macrophages and dendritic cells differentially induce regulatory and interleukin 17-producing T cell responses. Nat Immunol 2007;8:1086-1094. [PubMed: 17873879]

84. Roelofs-Haarhuis K, Wu X, Gleichmann E. Oral tolerance to nickel requires CD4+ invariant NKT cells for the infectious spread of tolerance and the induction of specific regulatory T cells. The Journal of Immunology 2004;173:1043-1050. [PubMed: 15240692]

85. Liu R, La CA, Bai XF, Jee Y, Price M, Campagnolo DI, Christadoss P, Vollmer TL, Van KL, Shi FD. Cooperation of invariant NKT cells and CD4+CD25+ T regulatory cells in the prevention of autoimmune myasthenia. The Journal of Immunology 2005;175:7898-7904. [PubMed: 16339525]

86. Qin S, Cobbold SP, Pope H, Elliott J, Kioussis D, Davies J, Waldmann H. "Infectious" transplantation tolerance. Science 1993;259:974-977. [PubMed: 8094901]

87. Cobbold SP, Castejon R, Adams E, Zelenika D, Graca L, Humm S, Waldmann H. Induction of foxP3 + regulatory $\mathrm{T}$ cells in the periphery of $\mathrm{T}$ cell receptor transgenic mice tolerized to transplants. The Journal of Immunology 2004;172:6003-6010. [PubMed: 15128783]

88. Dieckmann D, Bruett CH, Ploettner H, Lutz MB, Schuler G. Human CD4+CD25+ Regulatory, Contact-dependent T Cells Induce Interleukin 10-producing, Contact-independent Type 1-like Regulatory T Cells. The Journal of Experimental Medicine 2002;196:247-253. [PubMed: 12119349]

89. Jonuleit H, Schmitt E, Kakirman H, Stassen M, Knop J, Enk AH. Infectious Tolerance: Human CD25 + Regulatory T Cells Convey Suppressor Activity to Conventional CD4+ T Helper Cells. The Journal of Experimental Medicine 2002;196:255-260. [PubMed: 12119350]

90. Korn T, Bettelli E, Oukka M, Kuchroo VK. IL-17 and Th17 Cells. Annu Rev Immunol. 2009

91. Bettelli E, Carrier Y, Gao W, Korn T, Strom TB, Oukka M, Weiner HL, Kuchroo VK. Reciprocal developmental pathways for the generation of pathogenic effector TH17 and regulatory T cells. Nature 2006;441:235-238. [PubMed: 16648838]

92. Xu L, Kitani A, Fuss I, Strober W. Cutting edge: regulatory T cells induce CD4+CD25-Foxp3- T cells or are self-induced to become Th17 cells in the absence of exogenous TGF-beta. J Immunol 2007;178:6725-6729. [PubMed: 17513718]

93. Roncarolo MG, Gregori S, Battaglia M, Bacchetta R, Fleischhauer K, Levings MK. Interleukin-10secreting type 1 regulatory T cells in rodents and humans. Immunol Rev 2006;212:28-50. [PubMed: 16903904]

94. Bacchetta R, Sartirana C, Levings MK, Bordignon C, Narula S, Roncarolo MG. Growth and expansion of human T regulatory type 1 cells are independent from TCR activation but require exogenous cytokines. Eur.J Immunol 2002;32:2237-2245. [PubMed: 12209636]

95. Barrat FJ, Cua DJ, Boonstra A, Richards DF, Crain C, Savelkoul HF, de Waal-Malefyt R, Coffman RL, Hawrylowicz CM, O'Garra A. In vitro generation of interleukin 10-producing regulatory CD4 (+) T cells is induced by immunosuppressive drugs and inhibited by Thelper type 1 (Th1)- and Th2inducing cytokines. The Journal of Experimental Medicine 2002;195:603-616. [PubMed: 11877483]

96. Burkhart C, Liu GY, Anderton SM, Metzler B, Wraith DC. Peptide-induced T cell regulation of experimental autoimmune encephalomyelitis: a role for IL-10. International Immunology 1999;11:1625-1634. [PubMed: 10508180]

97. Curotto de Lafaille MA, Kutchukhidze N, Shen S, Ding Y, Yee H, Lafaille JJ. Adaptive Foxp3+ regulatory $\mathrm{T}$ cell-dependent and -independent control of allergic inflammation. Immunity 2008;29:114-126. [PubMed: 18617425] 
98. Curotto de Lafaille MA, Lino AC, Kutchukhidze N, Lafaille JJ. CD25-T Cells Generate CD25+Foxp3 + Regulatory T Cells by Peripheral Expansion. The Journal of Immunology 2004;173:7259-7268. [PubMed: 15585848]

99. Mucida D, Kutchukhidze N, Erazo A, Russo M, Lafaille JJ, Curotto de Lafaille MA. Oral tolerance in the absence of naturally occurring Tregs. J Clin.Invest 2005;115:1923-1933. [PubMed: 15937545]

100. Fukaura H, Kent SC, Pietrusewicz MJ, Khoury SJ, Weiner HL, Hafler DA. Induction of circulating myelin basic protein and proteolipid protein-specific transforming growth factor-beta1-secreting Th3 T cells by oral administration of myelin in multiple sclerosis patients. J Clin Invest 1996;98:7077. [PubMed: 8690806]

101. Li MO, Wan YY, Flavell RA. T cell-produced transforming growth factor-beta1 controls T cell tolerance and regulates Th1- and Th17-cell differentiation. Immunity 2007;26:579-591. [PubMed: 17481928]

102. Mamura M, Lee W, Sullivan TJ, Felici A, Sowers AL, Allison JP, Letterio JJ. CD28 disruption exacerbates inflammation in Tgf- $\beta 1-/-$ mice: in vivo suppression by $\mathrm{CD} 4+\mathrm{CD} 25+$ regulatory $\mathrm{T}$ cells independent of autocrine TGF- $\beta 1$. Blood 2004;103:4594-4601. [PubMed: 15016653]

103. Fahlen L, Read S, Gorelik L, Hurst SD, Coffman RL, Flavell RA, Powrie F. T cells that cannot respond to TGF-beta escape control by CD4(+)CD25(+) regulatory T cells. The Journal of Experimental Medicine 2005;201:737-746. [PubMed: 15753207]

104. Chen ML, Pittet MJ, Gorelik L, Flavell RA, Weissleder R, von BH, Khazaie K. Regulatory T cells suppress tumor-specific CD8 T cell cytotoxicity through TGF-beta signals in vivo. Proc.Natl.Acad.Sci.U.S.A 2005;102:419-424. [PubMed: 15623559]

105. Hamann A, Andrew DP, Jablonski-Westrich D, Holzmann B, Butcher EC. Role of alpha 4-integrins in lymphocyte homing to mucosal tissues in vivo. The Journal of Immunology 1994;152:32823293. [PubMed: 7511642]

106. Iwata M, Hirakiyama A, Eshima Y, Kagechika H, Kato C, Song SY. Retinoic acid imprints guthoming specificity on T cells. Immunity 2004;21:527-538. [PubMed: 15485630]

107. Carroll MW, Overwijk WW, Surman DR, Tsung K, Moss B, Restifo NP. Construction and characterization of a triple-recombinant vaccinia virus encoding B7-1, interleukin 12, and a model tumor antigen. J.Natl.Cancer Inst 1998;90:1881-1887. [PubMed: 9862625]

108. Vignali D. How many mechanisms do regulatory T cells need? Eur J Immunol 2008;38:908-911. [PubMed: 18395857]

109. Tang Q, Bluestone JA. The Foxp3+ regulatory T cell: a jack of all trades, master of regulation. Nat.Immunol 2008;9:239-244. [PubMed: 18285775]

110. Sojka DK, Huang YH, Fowell DJ. Mechanisms of regulatory T-cell suppression - a diverse arsenal for a moving target. Immunology 2008;124:13-22. [PubMed: 18346152]

111. Gondek DC, Lu LF, Quezada SA, Sakaguchi S, Noelle RJ. Cutting edge: contact-mediated suppression by CD4+CD25+ regulatory cells involves a granzyme B-dependent, perforinindependent mechanism. Journal of Immunology 2005;174:1783-1786.

112. Cao X, Cai SF, Fehniger TA, Song J, Collins LI, Piwnica-Worms DR, Ley TJ. Granzyme B and perforin are important for regulatory $\mathrm{T}$ cell-mediated suppression of tumor clearance. Immunity 2007;27:635-646. [PubMed: 17919943]

113. Mellor AL, Munn DH. IDO expression by dendritic cells: tolerance and tryptophan catabolism. Nat.Rev.Immunol 2004;4:762-774. [PubMed: 15459668]

114. Mottet C, Uhlig HH, Powrie F. Cutting edge: cure of colitis by CD4+CD25+ regulatory T cells. J Immunol 2003;170:3939-3943. [PubMed: 12682220]

115. Collison LW, Workman CJ, Kuo TT, Boyd K, Wang Y, Vignali KM, Cross R, Sehy D, Blumberg RS, Vignali DA. The inhibitory cytokine IL-35 contributes to regulatory T-cell function. Nature 2007;450:566-569. [PubMed: 18033300]

116. Kuhn R, Lohler J, Rennick D, Rajewsky K, Muller W. Interleukin-10-deficient mice develop chronic enterocolitis. Cell 1993;75:263-274. [PubMed: 8402911]

117. Powrie F, Correa-Oliveira R, Mauze S, Coffman RL. Regulatory interactions between CD45RBhigh and CD45RBlow CD4+ T cells are important for the balance between protective and pathogenic cell-mediated immunity. J Exp Med 1994;179:589-600. [PubMed: 7905019] 
118. Asseman C, Mauze S, Leach MW, Coffman RL, Powrie F. An essential role for interleukin 10 in the function of regulatory T cells that inhibit intestinal inflammation. J Exp Med 1999;190:9951004. [PubMed: 10510089]

119. Asseman C, Read S, Powrie F. Colitogenic Th1 cells are present in the antigen-experienced T cell pool in normal mice: control by CD4+ regulatory T cells and IL-10. J Immunol 2003;171:971-978. [PubMed: 12847269]

120. Rubtsov YP, Rasmussen JP, Chi EY, Fontenot J, Castelli L, Ye X, Treuting P, Siewe L, Roers A, Henderson WR Jr, Muller W, Rudensky AY. Regulatory T cell-derived interleukin-10 limits inflammation at environmental interfaces. Immunity 2008;28:546-558. [PubMed: 18387831]

121. Uhlig HH, Coombes J, Mottet C, Izcue A, Thompson C, Fanger A, Tannapfel A, Fontenot JD, Ramsdell F, Powrie F. Characterization of Foxp3+CD4+CD25+ and IL-10-secreting CD4+CD25 + T cells during cure of colitis. J Immunol 2006;177:5852-5860. [PubMed: 17056509]

122. Hvas CL, Kelsen J, Agnholt J, Hollsberg P, Tvede M, Moller JK, Dahlerup JF. Crohn's disease intestinal CD4+ T cells have impaired interleukin-10 production which is not restored by probiotic bacteria. Scand J Gastroenterol 2007;42:592-601. [PubMed: 17454880]

123. Kulkarni AB, Huh CG, Becker D, Geiser A, Lyght M, Flanders KC, Roberts AB, Sporn MB, Ward $\mathrm{JM}$, Karlsson S. Transforming growth factor beta 1 null mutation in mice causes excessive inflammatory response and early death. Proc Natl Acad Sci U S A 1993;90:770-774. [PubMed: 8421714]

124. Fahlen L, Read S, Gorelik L, Hurst SD, Coffman RL, Flavell RA, Powrie F. T cells that cannot respond to TGF-beta escape control by CD4(+)CD25(+) regulatory T cells. J Exp Med 2005;201:737-746. [PubMed: 15753207]

125. Powrie F, Carlino J, Leach MW, Mauze S, Coffman RL. A critical role for transforming growth factor-beta but not interleukin 4 in the suppression of T helper type 1-mediated colitis by CD45RB (low) CD4+ T cells. J Exp Med 1996;183:2669-2674. [PubMed: 8676088]

126. Oida T, Zhang X, Goto M, Hachimura S, Totsuka M, Kaminogawa S, Weiner HL. CD4+CD25- T cells that express latency-associated peptide on the surface suppress CD4+CD45RBhigh-induced colitis by a TGF-beta-dependent mechanism. J Immunol 2003;170:2516-2522. [PubMed: 12594277]

127. Kullberg MC, Hay V, Cheever AW, Mamura M, Sher A, Letterio JJ, Shevach EM, Piccirillo CA. TGF-beta1 production by CD4+ CD25+ regulatory T cells is not essential for suppression of intestinal inflammation. Eur J Immunol 2005;35:2886-2895. [PubMed: 16180248]

128. Kang SG, Lim HW, Andrisani OM, Broxmeyer HE, Kim CH. Vitamin A metabolites induce guthoming FoxP3+ regulatory T cells. J Immunol 2007;179:3724-3733. [PubMed: 17785809]

129. Collison LW, Pillai MR, Chaturvedi V, Vignali DAA. Regulatory T cell suppression is potentiated by target T cells in a cell contact, IL-35- and IL-10-dependent manner. J Immunol. 2009(in press).

130. Bardel E, Larousserie F, Charlot-Rabiega P, Coulomb-L'Hermine A, Devergne O. Human CD4+ CD25+ Foxp3+ regulatory T cells do not constitutively express IL-35. J Immunol 2008;181:68986905. [PubMed: 18981109]

131. Lewkowich IP, Herman NS, Schleifer KW, Dance MP, Chen BL, Dienger KM, Sproles AA, Shah JS, Kohl J, Belkaid Y, Wills-Karp M. CD4+CD25+ T cells protect against experimentally induced asthma and alter pulmonary dendritic cell phenotype and function. J Exp Med 2005;202:1549-1561. [PubMed: 16314437]

132. Ling EM, Smith T, Nguyen XD, Pridgeon C, Dallman M, Arbery J, Carr VA, Robinson DS. Relation of CD4+CD25+ regulatory T-cell suppression of allergen-driven T-cell activation to atopic status and expression of allergic disease. Lancet 2004;363:608-615. [PubMed: 14987885]

133. Ou LS, Goleva E, Hall C, Leung DY. T regulatory cells in atopic dermatitis and subversion of their activity by superantigens. J Allergy Clin Immunol 2004;113:756-763. [PubMed: 15100684]

134. Hartl D, Koller B, Mehlhorn AT, Reinhardt D, Nicolai T, Schendel DJ, Griese M, Krauss-Etschmann S. Quantitative and functional impairment of pulmonary CD4+CD25hi regulatory T cells in pediatric asthma. J Allergy Clin Immunol 2007;119:1258-1266. [PubMed: 17412402]

135. Akdis CA, Blesken T, Akdis M, Wuthrich B, Blaser K. Role of interleukin 10 in specific immunotherapy. J Clin Invest 1998;102:98-106. [PubMed: 9649562] 
136. Kearley J, Barker JE, Robinson DS, Lloyd CM. Resolution of airway inflammation and hyperreactivity after in vivo transfer of CD4+CD25+ regulatory T cells is interleukin 10 dependent. J Exp Med 2005;202:1539-1547. [PubMed: 16314435]

137. Ostroukhova M, Seguin-Devaux C, Oriss TB, Dixon-McCarthy B, Yang L, Ameredes BT, Corcoran TE, Ray A. Tolerance induced by inhaled antigen involves CD4(+) T cells expressing membranebound TGF-beta and FOXP3. J Clin Invest 2004;114:28-38. [PubMed: 15232609]

138. Akbari O, Freeman GJ, Meyer EH, Greenfield EA, Chang TT, Sharpe AH, Berry G, DeKruyff RH, Umetsu DT. Antigen-specific regulatory T cells develop via the ICOS-ICOS-ligand pathway and inhibit allergen-induced airway hyperreactivity. Nat Med 2002;8:1024-1032. [PubMed: 12145647]

139. Oh JW, Seroogy CM, Meyer EH, Akbari O, Berry G, Fathman CG, Dekruyff RH, Umetsu DT. CD4 T-helper cells engineered to produce IL-10 prevent allergen-induced airway hyperreactivity and inflammation. J Allergy Clin Immunol 2002;110:460-468. [PubMed: 12209095]

140. Hansen G, McIntire JJ, Yeung VP, Berry G, Thorbecke GJ, Chen L, DeKruyff RH, Umetsu DT. CD4(+) T helper cells engineered to produce latent TGF-beta1 reverse allergen-induced airway hyperreactivity and inflammation. J Clin Invest 2000;105:61-70. [PubMed: 10619862]

141. Presser K, Schwinge D, Wegmann M, Huber S, Schmitt S, Quaas A, Maxeiner JH, Finotto S, Lohse AW, Blessing M, Schramm C. Coexpression of TGF-beta1 and IL-10 enables regulatory T cells to completely suppress airway hyperreactivity. J Immunol 2008;181:7751-7758. [PubMed: 19017964]

142. Meiler F, Zumkehr J, Klunker S, Ruckert B, Akdis CA, Akdis M. In vivo switch to IL-10-secreting T regulatory cells in high dose allergen exposure. J Exp Med 2008;205:2887-2898. [PubMed: 19001136]

143. Meiler F, Klunker S, Zimmermann M, Akdis CA, Akdis M. Distinct regulation of IgE, IgG4 and IgA by T regulatory cells and toll-like receptors. Allergy 2008;63:1455-1463. [PubMed: 18925882]

144. Wilson MS, Pesce JT, Ramalingam TR, Thompson RW, Cheever A, Wynn TA. Suppression of murine allergic airway disease by IL-2:anti-IL-2 monoclonal antibody-induced regulatory T cells. J Immunol 2008;181:6942-6954. [PubMed: 18981114]

145. Boyman O, Surh CD, Sprent J. Potential use of IL-2/anti-IL-2 antibody immune complexes for the treatment of cancer and autoimmune disease. Expert Opin Biol Ther 2006;6:1323-1331. [PubMed: 17223740]

146. Bach JF, Chatenoud L. Tolerance to islet autoantigens in type 1 diabetes. Annu Rev Immunol 2001;19:131-161. [PubMed: 11244033]

147. You S, Alyanakian MA, Segovia B, Damotte D, Bluestone J, Bach JF, Chatenoud L. Immunoregulatory pathways controlling progression of autoimmunity in NOD mice. Ann N Y Acad Sci 2008;1150:300-310. [PubMed: 19120317]

148. Wu AJ, Hua H, Munson SH, McDevitt HO. Tumor necrosis factor-alpha regulation of CD4+CD25 + T cell levels in NOD mice. Proc Natl Acad Sci U S A 2002;99:12287-12292. [PubMed: 12221281]

149. Szanya V, Ermann J, Taylor C, Holness C, Fathman CG. The subpopulation of CD4+CD25+ splenocytes that delays adoptive transfer of diabetes expresses L-selectin and high levels of CCR7. J Immunol 2002;169:2461-2465. [PubMed: 12193715]

150. You S, Belghith M, Cobbold S, Alyanakian MA, Gouarin C, Barriot S, Garcia C, Waldmann H, Bach JF, Chatenoud L. Autoimmune diabetes onset results from qualitative rather than quantitative age-dependent changes in pathogenic T-cells. Diabetes 2005;54:1415-1422. [PubMed: 15855328]

151. Lawson JM, Tremble J, Dayan C, Beyan H, Leslie RD, Peakman M, Tree TI. Increased resistance to $\mathrm{CD} 4+\mathrm{CD} 25 \mathrm{hi}$ regulatory $\mathrm{T}$ cell-mediated suppression in patients with type 1 diabetes. Clin Exp Immunol 2008;154:353-359. [PubMed: 19037920]

152. You S, Leforban B, Garcia C, Bach JF, Bluestone JA, Chatenoud L. Adaptive TGF-beta-dependent regulatory $\mathrm{T}$ cells control autoimmune diabetes and are a privileged target of anti-CD3 antibody treatment. Proc Natl Acad Sci U S A 2007;104:6335-6340. [PubMed: 17389382]

153. Billiard F, Litvinova E, Saadoun D, Djelti F, Klatzmann D, Cohen JL, Marodon G, Salomon BL. Regulatory and effector T cell activation levels are prime determinants of in vivo immune regulation. J Immunol 2006;177:2167-2174. [PubMed: 16887976] 
154. Tarbell KV, Yamazaki S, Olson K, Toy P, Steinman RM. CD25+ CD4+ T cells, expanded with dendritic cells presenting a single autoantigenic peptide, suppress autoimmune diabetes. J Exp Med 2004;199:1467-1477. [PubMed: 15184500]

155. Salomon B, Lenschow DJ, Rhee L, Ashourian N, Singh B, Sharpe A, Bluestone JA. B7/CD28 costimulation is essential for the homeostasis of the CD4+CD25+ immunoregulatory $\mathrm{T}$ cells that control autoimmune diabetes. Immunity 2000;12:431-440. [PubMed: 10795741]

156. Herold KC, Hagopian W, Auger JA, Poumian-Ruiz E, Taylor L, Donaldson D, Gitelman SE, Harlan $\mathrm{DM}, \mathrm{Xu}$ d, Zivin RA, Bluestone JA. Anti-CD3 monoclonal antibody in new-onset type 1 diabetes mellitus. N Engl J Med 2002;346:1692-1698. [PubMed: 12037148]

157. Herold KC, Gitelman SE, Masharani U, Hagopian W, Bisikirska B, Donaldson D, Rother K, Diamond B, Harlan DM, Bluestone JA. A single course of anti-CD3 monoclonal antibody hOKT3gamma1(Ala-Ala) results in improvement in C-peptide responses and clinical parameters for at least 2 years after onset of type 1 diabetes. Diabetes 2005;54:1763-1769. [PubMed: 15919798]

158. Battaglia M, Stabilini A, Draghici E, Migliavacca B, Gregori S, Bonifacio E, Roncarolo MG. Induction of tolerance in type 1 diabetes via both CD4+CD25+ T regulatory cells and T regulatory type 1 cells. Diabetes 2006;55:1571-1580. [PubMed: 16731819]

159. Tang Q, Henriksen KJ, Bi M, Finger EB, Szot G, Ye J, Masteller EL, McDevitt H, Bonyhadi M, Bluestone JA. In vitro-expanded antigen-specific regulatory T cells suppress autoimmune diabetes. J Exp Med 2004;199:1455-1465. [PubMed: 15184499]

160. McFarland HF, Martin R. Multiple sclerosis: a complicated picture of autoimmunity. Nat Immunol 2007;8:913-919. [PubMed: 17712344]

161. Viglietta V, Baecher-Allan C, Weiner HL, Hafler DA. Loss of functional suppression by CD4+CD25 + regulatory T cells in patients with multiple sclerosis. J Exp Med 2004;199:971-979. [PubMed: 15067033]

162. Haas J, Hug A, Viehover A, Fritzsching B, Falk CS, Filser A, Vetter T, Milkova L, Korporal M, Fritz B, Storch-Hagenlocher B, Krammer PH, Suri-Payer E, Wildemann B. Reduced suppressive effect of CD4+CD25high regulatory $\mathrm{T}$ cells on the $\mathrm{T}$ cell immune response against myelin oligodendrocyte glycoprotein in patients with multiple sclerosis. Eur J Immunol 2005;35:33433352. [PubMed: 16206232]

163. Venken K, Hellings N, Hensen K, Rummens JL, Medaer R, D'Hooghe MB, Dubois B, Raus J, Stinissen P. Secondary progressive in contrast to relapsing-remitting multiple sclerosis patients show a normal CD4+CD25+ regulatory T-cell function and FOXP3 expression. J Neurosci Res 2006;83:1432-1446. [PubMed: 16583400]

164. Huan J, Culbertson N, Spencer L, Bartholomew R, Burrows GG, Chou YK, Bourdette D, Ziegler SF, Offner H, Vandenbark AA. Decreased FOXP3 levels in multiple sclerosis patients. J Neurosci Res 2005;81:45-52. [PubMed: 15952173]

165. McGeachy MJ, Stephens LA, Anderton SM. Natural recovery and protection from autoimmune encephalomyelitis: contribution of CD4+CD25+ regulatory cells within the central nervous system. J Immunol 2005;175:3025-3032. [PubMed: 16116190]

166. Zhang X, Koldzic DN, Izikson L, Reddy J, Nazareno RF, Sakaguchi S, Kuchroo VK, Weiner HL. IL-10 is involved in the suppression of experimental autoimmune encephalomyelitis by CD25+CD4 + regulatory T cells. Int Immunol 2004;16:249-256. [PubMed: 14734610]

167. Spach KM, Nashold FE, Dittel BN, Hayes CE. IL-10 signaling is essential for 1,25-dihydroxyvitamin D3-mediated inhibition of experimental autoimmune encephalomyelitis. J Immunol 2006;177:6030-6037. [PubMed: 17056528]

168. Korn T, Reddy J, Gao W, Bettelli E, Awasthi A, Petersen TR, Backstrom BT, Sobel RA, Wucherpfennig KW, Strom TB, Oukka M, Kuchroo VK. Myelin-specific regulatory T cells accumulate in the CNS but fail to control autoimmune inflammation. Nat Med 2007;13:423-431. [PubMed: 17384649]

169. Liu GZ, Gomes AC, Putheti P, Karrenbauer V, Kostulas K, Press R, Hillert J, Hjelmstrom P, Gao XG. Increased soluble 4-1BB ligand (4-1BBL) levels in peripheral blood of patients with multiple sclerosis. Scand J Immunol 2006;64:412-419. [PubMed: 16970683] 
170. Zhang X, Reddy J, Ochi H, Frenkel D, Kuchroo VK, Weiner HL. Recovery from experimental allergic encephalomyelitis is TGF-beta dependent and associated with increases in CD4+LAP+ and CD4+CD25+ T cells. Int Immunol 2006;18:495-503. [PubMed: 16540527]

171. Chen ML, Yan BS, Bando Y, Kuchroo VK, Weiner HL. Latency-associated peptide identifies a novel CD4+CD25+ regulatory $\mathrm{T}$ cell subset with TGFbeta-mediated function and enhanced suppression of experimental autoimmune encephalomyelitis. J Immunol 2008;180:7327-7337. [PubMed: 18490732]

172. Mekala DJ, Alli RS, Geiger TL. IL-10-dependent suppression of experimental allergic encephalomyelitis by Th2-differentiated, anti-TCR redirected T lymphocytes. J Immunol 2005;174:3789-3797. [PubMed: 15749920]

173. Viguier M, Lemaitre F, Verola O, Cho MS, Gorochov G, Dubertret L, Bachelez H, Kourilsky P, Ferradini L. Foxp3 expressing CD4+CD25(high) regulatory T cells are overrepresented in human metastatic melanoma lymph nodes and inhibit the function of infiltrating $\mathrm{T}$ cells. Journal of Immunology 2004;173:1444-1453.

174. Yang ZZ, Novak AJ, Stenson MJ, Witzig TE, Ansell SM. Intratumoral CD4+CD25+ regulatory Tcell-mediated suppression of infiltrating CD4+ T cells in B-cell non-Hodgkin lymphoma. Blood 2006;107:3639-3646. [PubMed: 16403912]

175. Woo EY, Chu CS, Goletz TJ, Schlienger K, Yeh H, Coukos G, Rubin SC, Kaiser LR, June CH. Regulatory CD4(+)CD25(+) T cells in tumors from patients with early-stage non-small cell lung cancer and late-stage ovarian cancer. Cancer Res 2001;61:4766-4772. [PubMed: 11406550]

176. Curiel TJ, Coukos G, Zou L, Alvarez X, Cheng P, Mottram P, Evdemon-Hogan M, Conejo-Garcia JR, Zhang L, Burow M, Zhu Y, Wei S, Kryczek I, Daniel B, Gordon A, Myers L, Lackner A, Disis ML, Knutson KL, Chen L, Zou W. Specific recruitment of regulatory T cells in ovarian carcinoma fosters immune privilege and predicts reduced survival. Nat.Med 2004;10:942-949. [PubMed: 15322536]

177. Sato E, Olson SH, Ahn J, Bundy B, Nishikawa H, Qian F, Jungbluth AA, Frosina D, Gnjatic S, Ambrosone C, Kepner J, Odunsi T, Ritter G, Lele S, Chen YT, Ohtani H, Old LJ, Odunsi K. Intraepithelial CD8+ tumor-infiltrating lymphocytes and a high CD8+/regulatory $\mathrm{T}$ cell ratio are associated with favorable prognosis in ovarian cancer. Proc.Natl.Acad.Sci.U.S.A 2005;102:1853818543. [PubMed: 16344461]

178. Liyanage UK, Moore TT, Joo HG, Tanaka Y, Herrmann V, Doherty G, Drebin JA, Strasberg SM, Eberlein TJ, Goedegebuure PS, Linehan DC. Prevalence of regulatory T cells is increased in peripheral blood and tumor microenvironment of patients with pancreas or breast adenocarcinoma. Journal of Immunology 2002;169:2756-2761.

179. Kawaida H, Kono K, Takahashi A, Sugai H, Mimura K, Miyagawa N, Omata H, Ooi A, Fujii H. Distribution of CD4+CD25high regulatory T-cells in tumor-draining lymph nodes in patients with gastric cancer. J.Surg.Res 2005;124:151-157. [PubMed: 15734494]

180. Sasada T, Kimura M, Yoshida Y, Kanai M, Takabayashi A. CD4+CD25+ regulatory T cells in patients with gastrointestinal malignancies: possible involvement of regulatory $\mathrm{T}$ cells in disease progression. Cancer 2003;98:1089-1099. [PubMed: 12942579]

181. Ormandy LA, Hillemann T, Wedemeyer H, Manns MP, Greten TF, Korangy F. Increased populations of regulatory $\mathrm{T}$ cells in peripheral blood of patients with hepatocellular carcinoma. Cancer Res 2005;65:2457-2464. [PubMed: 15781662]

182. Salama P, Phillips M, Grieu F, Morris M, Zeps N, Joseph D, Platell C, Iacopetta B. Tumor-Infiltrating FOXP3+ T Regulatory Cells Show Strong Prognostic Significance in Colorectal Cancer. J.Clin.Oncol. 2008

183. Carreras J, Lopez-Guillermo A, Fox BC, Colomo L, Martinez A, Roncador G, Montserrat E, Campo E, Banham AH. High numbers of tumor-infiltrating FOXP3-positive regulatory T cells are associated with improved overall survival in follicular lymphoma. Blood 2006;108:2957-2964. [PubMed: 16825494]

184. Alvaro T, Lejeune M, Salvado MT, Bosch R, Garcia JF, Jaen J, Banham AH, Roncador G, Montalban C, Piris MA. Outcome in Hodgkin's lymphoma can be predicted from the presence of accompanying cytotoxic and regulatory T cells. Clin.Cancer Res 2005;11:1467-1473. [PubMed: 15746048]

185. Morgan ME, van Bilsen JH, Bakker AM, Heemskerk B, Schilham MW, Hartgers FC, Elferink BG, van der ZL, de Vries RR, Huizinga TW, Ottenhoff TH, Toes RE. Expression of FOXP3 mRNA is 
not confined to CD4+CD25+ T regulatory cells in humans. Human Immunology 2005;66:13-20. [PubMed: 15620457]

186. Allan SE, Crome SQ, Crellin NK, Passerini L, Steiner TS, Bacchetta R, Roncarolo MG, Levings MK. Activation-induced FOXP3 in human T effector cells does not suppress proliferation or cytokine production. Int.Immunol 2007;19:345-354. [PubMed: 17329235]

187. Tran DQ, Ramsey H, Shevach EM. Induction of FOXP3 expression in naive human CD4+FOXP3 $\mathrm{T}$ cells by T-cell receptor stimulation is transforming growth factor-beta dependent but does not confer a regulatory phenotype. Blood 2007;110:2983-2990. [PubMed: 17644734]

188. Onizuka S, Tawara I, Shimizu J, Sakaguchi S, Fujita T, Nakayama E. Tumor rejection by in vivo administration of anti-CD25 (interleukin-2 receptor alpha) monoclonal antibody. Cancer Res 1999;59:3128-3133. [PubMed: 10397255]

189. Shimizu J, Yamazaki S, Sakaguchi S. Induction of tumor immunity by removing CD25+CD4+ T cells: a common basis between tumor immunity and autoimmunity. Journal of Immunology 1999;163:5211-5218.

190. Ghiringhelli F, Menard C, Terme M, Flament C, Taieb J, Chaput N, Puig PE, Novault S, Escudier B, Vivier E, Lecesne A, Robert C, Blay JY, Bernard J, Caillat-Zucman S, Freitas A, Tursz T, Wagner-Ballon O, Capron C, Vainchencker W, Martin F, Zitvogel L. CD4+CD25+ regulatory T cells inhibit natural killer cell functions in a transforming growth factor-beta-dependent manner. The Journal of Experimental Medicine 2005;202:1075-1085. [PubMed: 16230475]

191. Gil-Guerrero L, Dotor J, Huibregtse IL, Casares N, Lopez-Vazquez AB, Rudilla F, Riezu-Boj JI, Lopez-Sagaseta J, Hermida J, Van DS, Bezunartea J, Llopiz D, Sarobe P, Prieto J, Borras-Cuesta F, Lasarte JJ. In vitro and in vivo down-regulation of regulatory $\mathrm{T}$ cell activity with a peptide inhibitor of TGF-beta1. Journal of Immunology 2008;181:126-135.

192. Loser K, Apelt J, Voskort M, Mohaupt M, Balkow S, Schwarz T, Grabbe S, Beissert S. IL-10 controls ultraviolet-induced carcinogenesis in mice. Journal of Immunology 2007;179:365-371.

193. Strauss L, Bergmann C, Szczepanski M, Gooding W, Johnson JT, Whiteside TL. A unique subset of CD4+CD25highFoxp3+ T cells secreting interleukin-10 and transforming growth factor-beta1 mediates suppression in the tumor microenvironment. Clin.Cancer Res 2007;13:4345-4354. [PubMed: 17671115]

194. Kryczek I, Wei S, Zou L, Zhu G, Mottram P, Xu H, Chen L, Zou W. Cutting edge: induction of B7H4 on APCs through IL-10: novel suppressive mode for regulatory T cells. Journal of Immunology 2006;177:40-44.

195. Kryczek I, Zou L, Rodriguez P, Zhu G, Wei S, Mottram P, Brumlik M, Cheng P, Curiel T, Myers L, Lackner A, Alvarez X, Ochoa A, Chen L, Zou W. B7-H4 expression identifies a novel suppressive macrophage population in human ovarian carcinoma. The Journal of Experimental Medicine 2006;203:871-881. [PubMed: 16606666]

196. Wing K, Onishi Y, Prieto-Martin P, Yamaguchi T, Miyara M, Fehervari Z, Nomura T, Sakaguchi S. CTLA-4 control over Foxp3+ regulatory T cell function. Science 2008;322:271-275. [PubMed: 18845758]

197. Fallarino F, sselin-Paturel C, Vacca C, Bianchi R, Gizzi S, Fioretti MC, Trinchieri G, Grohmann U, Puccetti P. Murine plasmacytoid dendritic cells initiate the immunosuppressive pathway of tryptophan catabolism in response to CD200 receptor engagement. Journal of Immunology 2004;173:3748-3754.

198. Sharma MD, Baban B, Chandler P, Hou DY, Singh N, Yagita H, Azuma M, Blazar BR, Mellor AL, Munn DH. Plasmacytoid dendritic cells from mouse tumor-draining lymph nodes directly activate mature Tregs via indoleamine 2,3-dioxygenase. J.Clin.Invest 2007;117:2570-2582. [PubMed: 17710230]

199. Fallarino F, Grohmann U, Hwang KW, Orabona C, Vacca C, Bianchi R, Belladonna ML, Fioretti MC, Alegre ML, Puccetti P. Modulation of tryptophan catabolism by regulatory T cells. Nat.Immunol 2003;4:1206-1212. [PubMed: 14578884]

200. Belkaid Y, Rouse BT. Natural regulatory T cells in infectious disease. Nat.Immunol 2005;6:353360. [PubMed: 15785761]

201. Belkaid Y, Piccirillo CA, Mendez S, Shevach EM, Sacks DL. CD4+CD25+ regulatory T cells control Leishmania major persistence and immunity. Nature 2002;420:502-507. [PubMed: 12466842] 
202. Hisaeda H, Maekawa Y, Iwakawa D, Okada H, Himeno K, Kishihara K, Tsukumo S, Yasutomo K. Escape of malaria parasites from host immunity requires CD4+CD25+ regulatory T cells. Nat.Med 2004;10:29-30. [PubMed: 14702631]

203. Netea MG, Sutmuller R, Hermann C, Van der Graaf CA, Van der Meer JW, van Krieken JH, Hartung T, Adema G, Kullberg BJ. Toll-like receptor 2 suppresses immunity against Candida albicans through induction of IL-10 and regulatory T cells. Journal of Immunology 2004;172:3712-3718.

204. Kursar M, Bonhagen K, Fensterle J, Kohler A, Hurwitz R, Kamradt T, Kaufmann SH, Mittrucker HW. Regulatory CD4+CD25+ T cells restrict memory CD8+ T cell responses. The Journal of Experimental Medicine 2002;196:1585-1592. [PubMed: 12486101]

205. Kursar M, Koch M, Mittrucker HW, Nouailles G, Bonhagen K, Kamradt T, Kaufmann SH. Cutting Edge: Regulatory T cells prevent efficient clearance of Mycobacterium tuberculosis. Journal of Immunology 2007;178:2661-2665.

206. Guyot-Revol V, Innes JA, Hackforth S, Hinks T, Lalvani A. Regulatory T cells are expanded in blood and disease sites in patients with tuberculosis. Am.J.Respir.Crit Care Med 2006;173:803810. [PubMed: 16339919]

207. Suvas S, Kumaraguru U, Pack CD, Lee S, Rouse BT. CD4+CD25+ T cells regulate virus-specific primary and memory CD8+ T cell responses. The Journal of Experimental Medicine 2003;198:889_ 901. [PubMed: 12975455]

208. Suvas S, Azkur AK, Kim BS, Kumaraguru U, Rouse BT. CD4+CD25+ regulatory T cells control the severity of viral immunoinflammatory lesions. Journal of Immunology 2004;172:4123-4132.

209. Cabrera R, Tu Z, Xu Y, Firpi RJ, Rosen HR, Liu C, Nelson DR. An immunomodulatory role for $\mathrm{CD} 4(+) \mathrm{CD} 25(+)$ regulatory $\mathrm{T}$ lymphocytes in hepatitis $\mathrm{C}$ virus infection. Hepatology 2004;40:1062-1071. [PubMed: 15486925]

210. Stoop JN, van der Molen RG, Baan CC, van der Laan LJ, Kuipers EJ, Kusters JG, Janssen HL. Regulatory $\mathrm{T}$ cells contribute to the impaired immune response in patients with chronic hepatitis B virus infection. Hepatology 2005;41:771-778. [PubMed: 15791617]

211. Aandahl EM, Michaelsson J, Moretto WJ, Hecht FM, Nixon DF. Human CD4+ CD25+ regulatory T cells control T-cell responses to human immunodeficiency virus and cytomegalovirus antigens. Journal of Virology 2004;78:2454-2459. [PubMed: 14963140]

212. Kinter AL, Hennessey M, Bell A, Kern S, Lin Y, Daucher M, Planta M, McGlaughlin M, Jackson R, Ziegler SF, Fauci AS. CD25(+)CD4(+) regulatory T cells from the peripheral blood of asymptomatic HIV-infected individuals regulate CD4(+) and CD8(+) HIV-specific T cell immune responses in vitro and are associated with favorable clinical markers of disease status. The Journal of Experimental Medicine 2004;200:331-343. [PubMed: 15280419]

213. Weiss L, Donkova-Petrini V, Caccavelli L, Balbo M, Carbonneil C, Levy Y. Human immunodeficiency virus-driven expansion of CD4+CD25+ regulatory T cells, which suppress HIVspecific CD4 T-cell responses in HIV-infected patients. Blood 2004;104:3249-3256. [PubMed: 15271794]

214. Scott-Browne JP, Shafiani S, Tucker-Heard G, Ishida-Tsubota K, Fontenot JD, Rudensky AY, Bevan MJ, Urdahl KB. Expansion and function of Foxp3-expressing T regulatory cells during tuberculosis. The Journal of Experimental Medicine 2007;204:2159-2169. [PubMed: 17709423]

215. Lund JM, Hsing L, Pham TT, Rudensky AY. Coordination of early protective immunity to viral infection by regulatory T cells. Science 2008;320:1220-1224. [PubMed: 18436744]

216. Belkaid Y. Role of Foxp3-positive regulatory T cells during infection. European Journal of Immunology 2008;38:918-921. [PubMed: 18395860]

217. Anderson CF, Oukka M, Kuchroo VJ, Sacks D. CD4(+)CD25(-)Foxp3(-) Th1 cells are the source of IL-10-mediated immune suppression in chronic cutaneous leishmaniasis. The Journal of Experimental Medicine 2007;204:285-297. [PubMed: 17283207] 


\section{Thymus}

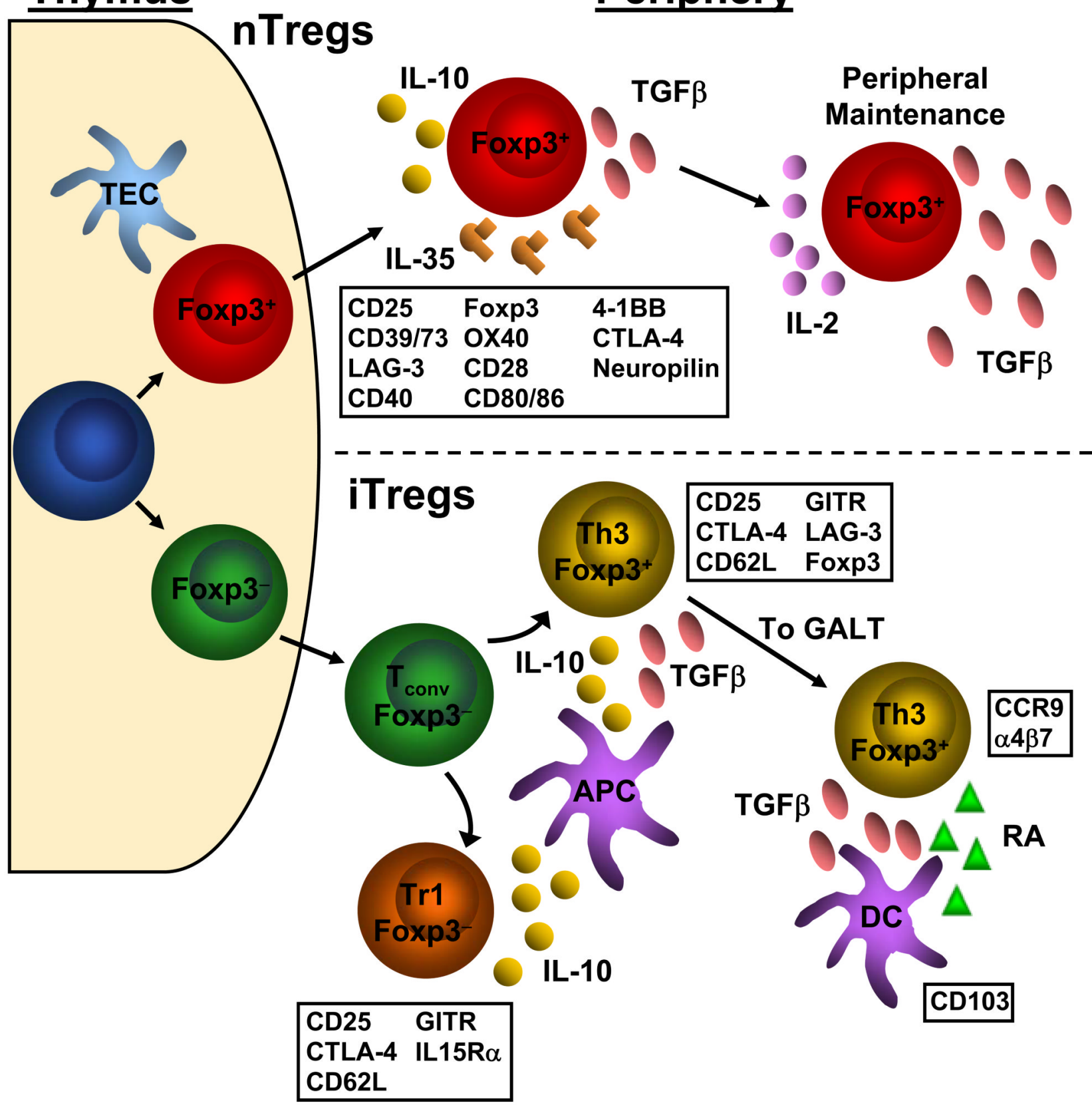

Figure 1. Development of nTregs and iTregs and the relevant markers associated with each. nTregs (top) differentiate from naïve conventional T cells to Foxp $3^{+}$Tregs in the thymus. In the periphery, natural Tregs express a number of cell surface markers, indicated in the box below the depiction of the natural Treg. However, none of these cell surface markers are unique to Tregs as they are also found on activated conventional T cells. Natural Tregs utilize the cytokines IL-10, IL-35 and TGF $\beta$ to exert their suppressive effects upon conventional T cells. TGF $\beta$ and IL-2 have also been shown to be important to the maintenance and fidelity of the Treg signature. iTregs (bottom) can be generated from conventional T cell precursors. Once in the periphery, naïve conventional T cells can be induced to become Foxp $3^{-}$Tr1 cells or Foxp $3^{+}$Th3 cells via IL-10 and/or TGF $\beta$ secreted by APCs such as dendritic cells and 
macrophages. These induced Tregs share similar cell surface markers as natural Tregs.

Foxp $3^{+}$induced Tregs can accumulate in the gut through upregulation of CCR9 and $\alpha 4 \beta 7$ via TGF $\beta$ and retinoic acid produced by $\mathrm{CD}_{103^{+}}$dendritic cells. TEC $=$thymic epithelial cell;

$\mathrm{T}_{\text {conv }}=$ conventional $\mathrm{T}$ cell; $\mathrm{DC}=$ dendritic cell; $\mathrm{RA}=$ retinoic acid 


\section{Inhibitory Cytokines}
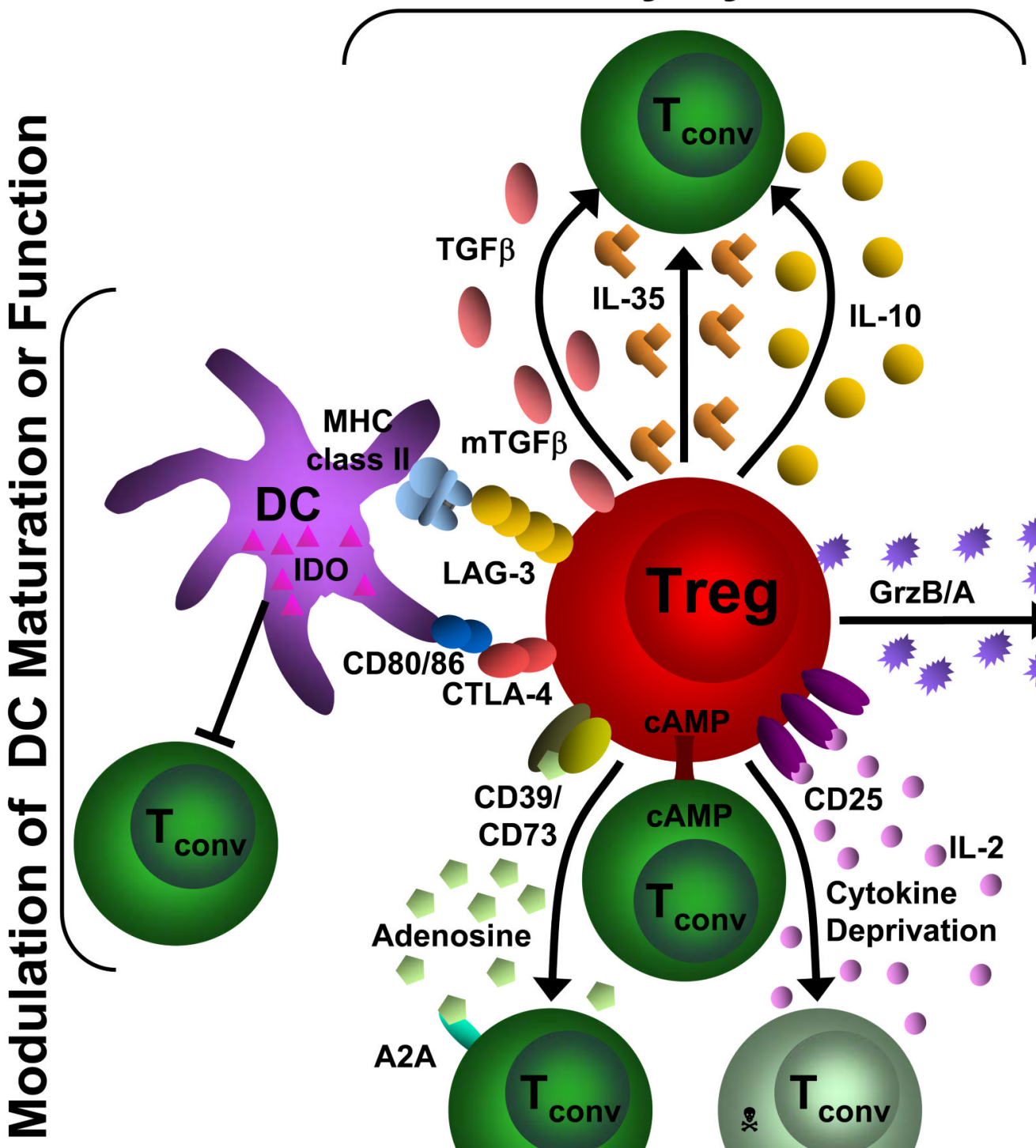
ITGF $\beta$

TGF $\beta$

DO
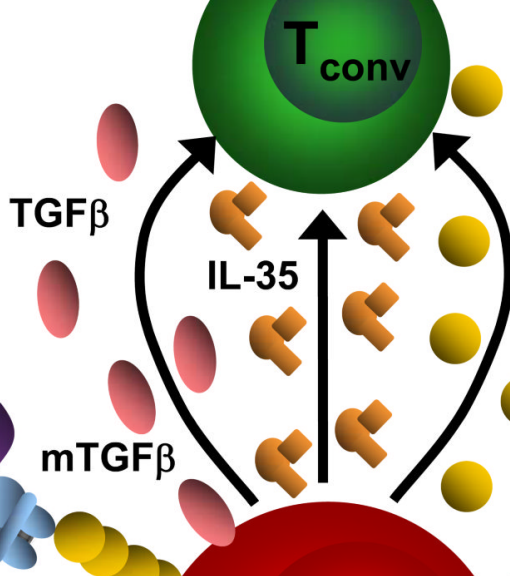

IL-10

LAG-3

CD80/86

CTLA-4

.

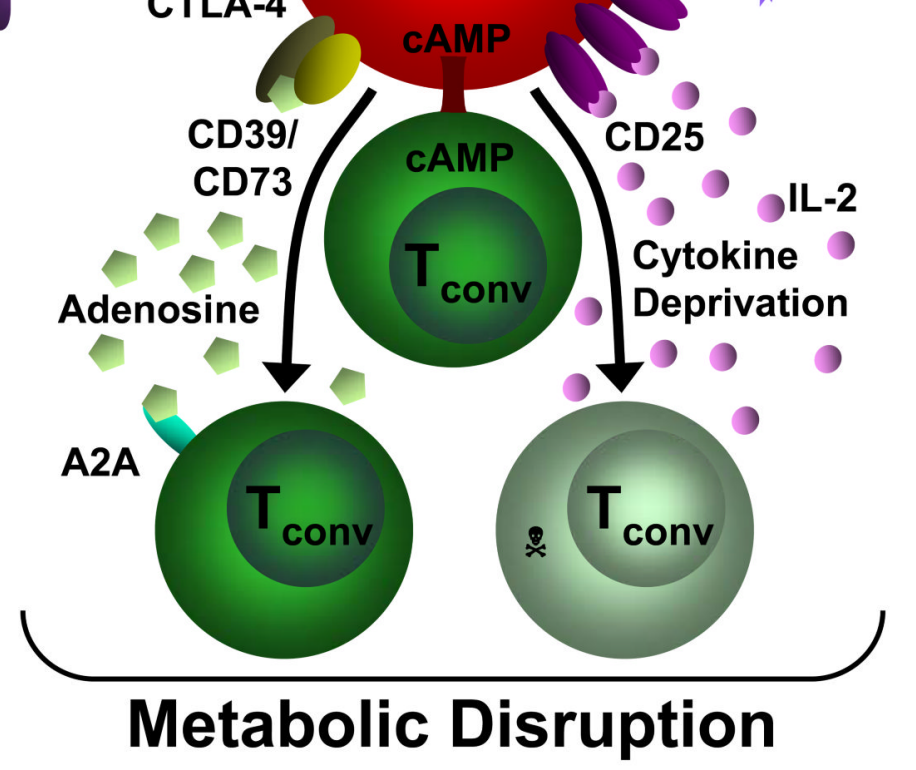

Figure 2. Mechanisms of Treg suppression.

This diagram depicts the four basic modes of Treg suppression. A primary mode of Treg suppression is mediated through the inhibitory cytokines IL-10, IL-35 and TGF $\beta$. Tregs also induce cytolysis through granzyme A/B (GrzB/A) and perforin (Pfr). They can disrupt metabolic function by IL-2 deprivation which results in apoptosis, cAMP inhibition or by CD39/CD73- generated A2A-mediated immunosuppression. Tregs can also modulate DC maturation or function via a CD80/86 and CTLA-4 interaction or through a LAG-3 and MHC class II interaction. In addition, they can induce the upregulation of IDO in DCs. $\mathrm{T}_{\text {conv }}=$ conventional $\mathrm{T}$ cell; $\mathrm{GrzB} / \mathrm{A}=$ granzyme $\mathrm{B}$ or $\mathrm{A}, \mathrm{Pfr}=$ perforin, $\mathrm{cAMP}=$ cyclic adenosine 
monophosphate, $\mathrm{A} 2 \mathrm{~A}=$ adenosine-purinergic adenosine receptor, $\mathrm{IDO}=$ indoleamine 2,3dioxygenase, $\mathrm{DC}=$ dendritic cell 